\title{
Antarctic icebergs distributions, 2002-2010
}

\author{
Jean Tournadre, ${ }^{1}$ Fanny Girard-Ardhuin, ${ }^{1}$ and Benoit Legrésy ${ }^{2}$ \\ Received 8 July 2011; revised 15 March 2012; accepted 16 March 2012; published 1 May 2012.
}

[1] Interest for icebergs and their possible impact on southern ocean circulation and biology has increased during the recent years. While large tabular icebergs are routinely tracked and monitored using scatterometer data, the distribution of smaller icebergs (less than some $\mathrm{km}$ ) is still largely unknown as they are difficult to detect operationally using conventional satellite data. In a recent study, Tournadre et al. (2008) showed that small icebergs can be detected, at least in open water, using high resolution $(20 \mathrm{~Hz})$ altimeter waveforms. In the present paper, we present an improvement of their method that allows, assuming a constant iceberg freeboard elevation and constant ice backscatter coefficient, to estimate the top-down iceberg surface area and therefore the distribution of the volume of ice on a monthly basis. The complete Jason-1 reprocessed (version C) archive covering the 2002-2010 period has been processed using this method. The small iceberg data base for the southern ocean gives an unprecedented description of the small iceberg $(100 \mathrm{~m}-2800 \mathrm{~m})$ distribution at unprecedented time and space resolutions. The iceberg size, which follows a lognormal distribution with an overall mean length of $630 \mathrm{~m}$, has a strong seasonal cycle reflecting the melting of icebergs during the austral summer estimated at $1.5 \mathrm{~m} /$ day. The total volume of ice in the southern ocean has an annual mean value of about $400 \mathrm{Gt}$, i.e., about $35 \%$ of the mean yearly volume of large tabular icebergs estimated from the National Ice Center database of 1979-2003 iceberg tracks and a model of iceberg thermodynamics. They can thus play a significant role in the injection of meltwater in the ocean. The distribution of ice volume which has strong seasonal cycle presents a very high spatial and temporal variability which is much contrasted in the three ocean basins (South Atlantic, Indian and Pacific oceans). The analysis of the relationship between small and large $(>5 \mathrm{~km})$ icebergs shows that a majority of small icebergs are directly associated with the large ones but that there are vast regions, such as the eastern branch of the Wedell Gyre, where the transport of ice is made only through the smaller ones.

Citation: Tournadre, J., F. Girard-Ardhuin, and B. Legrésy (2012), Antarctic icebergs distributions, 2002-2010, J. Geophys. Res., 117, C05004, doi:10.1029/2011JC007441.

\section{Introduction}

[2] Interest in icebergs has been growing in recent years (see for example the recent review by Smith [2011] as they may account for a significant part of the freshwater flux in the southern ocean [Silva et al., 2006; Martin and Adcroft, 2010; Gladstone et al., 2001; Jongma et al., 2009], and because they have been shown to transport nutriments (in particular labile iron) that could have a significant impact on ocean primary productivity [Schodlok et al., 2006; Raiswell et al., 2008; Lancelot et al., 2009; Schwarz and Schodlok, 2009]. Contrary to large tabular icebergs that are routinely tracked

\footnotetext{
${ }^{1}$ Laboratoire d'Océanographie Spatiale, Ifremer, Plouzane, France. ${ }^{2}$ LEGOS, CNRS-CNES-IRD-UPS, Toulouse, France.

Corresponding Author: J. Tournadre, IFREMER, Laboratoire d'Océanographie Spatiale, BP70, F-29280 Plouzané, France. (jean.tournadre@ifremer.fr)

Copyright 2012 by the American Geophysical Union. 0148-0227/12/2011JC007441
}

and monitored using scatterometer data [Long et al., 2002], the distribution of smaller icebergs, i.e., less than $2-3 \mathrm{~km}$ in length, in the southern ocean is known mainly from shipbased observations with a limited temporal and spatial coverage [Jacka and Giles, 2007; Wadhams, 1988; Romanov et al., 2008]. Indeed, they are difficult to detect operationally using satellite borne sensors. Visible and infrared sensors are often blinded by clouds while low resolution microwave sensors, such as radiometers, cannot detect such small features. Microwave scatterometer have been used regionally and with limitations to establish statistics on icebergs in coastal areas [Young et al., 1998]. Synthetic Aperture Radars, although their detecting capabilities have been demonstrated [Gladstone and Bigg, 2002; Silva and Bigg, 2005] they have yet to be used on an operational basis to produce iceberg distribution or climatology, mainly due to the large amount of data to be processed.

[3] In a recent study, Tournadre et al. [2008] demonstrated that small icebergs, at least in open water, have a significant signature in the noise part of high resolution (HR) 
altimeter waveforms and that the analysis of Jason altimeter HR waveforms over the southern ocean enables to determine the small iceberg distribution on a monthly basis. However, their study covers only one year of Jason-1 data. The recent availability of the reprocessed Jason 1 archive, which now covers more than 9 years, allows a first estimate of small iceberg climatology. The distribution of small icebergs is certainly of importance per se for climate studies, but for the analysis of the impact of icebergs on biomass, for the estimate of fresh water flux in the ocean or for ocean circulation, the volume of ice is certainly a more pertinent parameter. The detection method proposed by Tournadre et al. [2008], which provides only the location of icebergs and an estimate of the minimum iceberg freeboard height, is here improved to provide an estimate, under the assumption of a constant ice backscatter and on a constant iceberg freeboard elevation, of the top-down iceberg surface area and volume that are then used to compute the monthly distribution of the volume of ice (see section 2). In section 3, the analysis of the spatiotemporal variability of the distribution of iceberg size and of the volume of ice from 2002 to 2010 is presented; their relation with large icebergs is then investigated in section 4 while the final section gives an estimate of the quantity of fresh water available from small icebergs in the southern ocean.

\section{The Iceberg Data Set}

\subsection{Analysis of Jason-1 Archives (2002-2010)}

[4] The CNES/NASA Jason-1 mission, launched on December 7 th, 2001, was designed to ensure the continuity of the observation and monitoring of the ocean provided by Topex/Poseidon and it has basically the same characteristics. Its main instrument is the Poseidon-2 altimeter, which was derived from the experimental Poseidon-1 altimeter on board Topex/Poseidon. Poseidon-2 is a dual frequency radar operating at $13.6 \mathrm{GHz}$ ( $\mathrm{Ku}$ band) and $5.3 \mathrm{GHz}$ (C band). Depending on sea state, the altimeter footprint varies from 5 to $10 \mathrm{~km}$ radius. The satellite samples the ocean surface between $66^{\circ} \mathrm{S}$ and $66^{\circ} \mathrm{N}$ at a 0.05 -s interval for each of the 254 passes that make up a 9.9156-day repeat cycle. A detailed description of the Poseidon-2 altimeter is given in Ménard and Fu [2001]. The main Jason-1 altimeter characteristics are the following: altitude $1324 \mathrm{~km}$, inclination $66^{\circ}$, waveform frequency $20 \mathrm{~Hz}$, pulse repetition frequency $1800 \mathrm{~Hz}$, number of waveforms on average 90 per $0.05 \mathrm{~s}$, telemetry bin width $3.125 \mathrm{~ns}$, nominal track point 32.5.

[5] The CLS/AVISO Sensor Geophysical Data Records (SGDR version $\mathrm{C}$ ) data set that contains the high resolution $(20 \mathrm{~Hz})$ altimeter waveforms given in telemetry bins (gate) of width $3.125 \mathrm{~ns}$ (length of the pulse) is used in the present study. This data set is available upon request at the AVISO Center (http://www.aviso.oceanobs.com). These $20 \mathrm{~Hz}$ waveforms are themselves an average of 90 individual echoes to reduce the speckle noise. The distance between two consecutive HR waveforms is $290 \mathrm{~m}$.

[6] Nine years of Jason-1 $\mathrm{Ku}$ and C-band $20 \mathrm{~Hz}$ waveforms from January 25th, 2002 to December 31st, 2010 (cycles 2 to 331) have been processed using the detection method presented by Tournadre et al. [2008] to produce an iceberg database for the southern ocean. A detailed description of the method is given in Appendix A. Basically an altimeter is a nadir looking radar that emits short pulses that are backscattered by the sea surface. The altimeter measures the backscattered power as a function of time to construct the echo waveform from which the geophysical parameters are estimated. Targets emerging from the sea surface, such as icebergs or ships, can produce a detectable echo before the sea surface, i.e., in the noise part of the altimeter waveforms [Tournadre, 2007]. This signature is detectable, if the backscattered power is high enough to come out of the thermal noise of the sensor and if the time of the echo is within the measurement window of the system. This signature has a parabolic shape in the waveform space that depends only on the characteristics of the satellite orbit and can be easily detected using convolution analysis. The detection algorithm proposed by Tournadre et al. [2008] gives the location of the icebergs as well as the time of the echo $t_{e c h}$ and the power backscattered by the iceberg, $\sigma_{i c e b}$.

[7] More than fifty-two thousand iceberg signatures were detected and analyzed in open water between $66^{\circ} \mathrm{S}$ and $45^{\circ} \mathrm{S}$ for the $2002-2010$ period. Due to the $66^{\circ}$ inclination of the Jason-1 orbit, the satellite inter-track distance decreases with latitude up to $66^{\circ} \mathrm{S}$ (from $315 \mathrm{~km}$ at the equator to $132 \mathrm{~km}$ at $\left.65^{\circ} \mathrm{S}\right)$. As the density of altimeter data available on a regular grid thus increases poleward with latitude, the number of detected icebergs will be biased toward larger values at a higher latitude. To obtain a spatially consistent distribution it is thus necessary to consider the probability of the presence of icebergs rather than the number of detections. This probability $P$ of the presence of icebergs is simply the ratio of the number $N$ of icebergs detected within a grid cell by the number $N_{s}$ of valid Jason-1 samples within the same grid cell

$$
P(i, j)=N(i, j) / N_{s}(i, j) \text {. }
$$

\subsection{Estimate of the Icebergs Area and Ice Volume}

\subsubsection{Iceberg Area}

[8] The method of detection provides the time of the echo (i.e., the range) as well as the mean backscatter. The range depends on the distance $d$ from nadir of the iceberg center and on the freeboard elevation $h$ of the iceberg. In their study, Tournadre et al. [2008] estimated the minimum freeboard of an iceberg, i.e., the freeboard that an iceberg would have if located at the satellite nadir $(d=0)$. The mean backscatter depends not only on the area, $A$, and on the distance from nadir but also on the backscattering coefficient of the iceberg surface, $\sigma_{0}^{i c e}$, which is conditioned by the ice characteristics, the shape and roughness of the iceberg surface, and the presence on the iceberg surface of snow or water. The two parameters, $t_{e c h}$ and $\sigma_{i c e b}$, are thus function of four main unknowns, $d, A, h$ and $\sigma_{0}^{i c e}$. The iceberg area can be estimated if assumptions are made on the values of two of the remaining unknowns $\left(d, h \sigma_{0}^{i c e}\right)$.

[9] First, we assume that the backscatter coefficient of the iceberg surface is the same for all icebergs. This assumption is certainly quite a crude approximation and has to be verified at least at a first order. Let us first assume that the largest measured backscatter corresponds to the largest icebergs, i.e., icebergs that almost completely fill the altimeter footprint and that the size of the largest detectable icebergs varies only weakly with time, latitude and longitude. The analysis of the maximum of $\sigma_{i c e b}$ as a function of latitude, longitude and time can then be used to validate at first order 

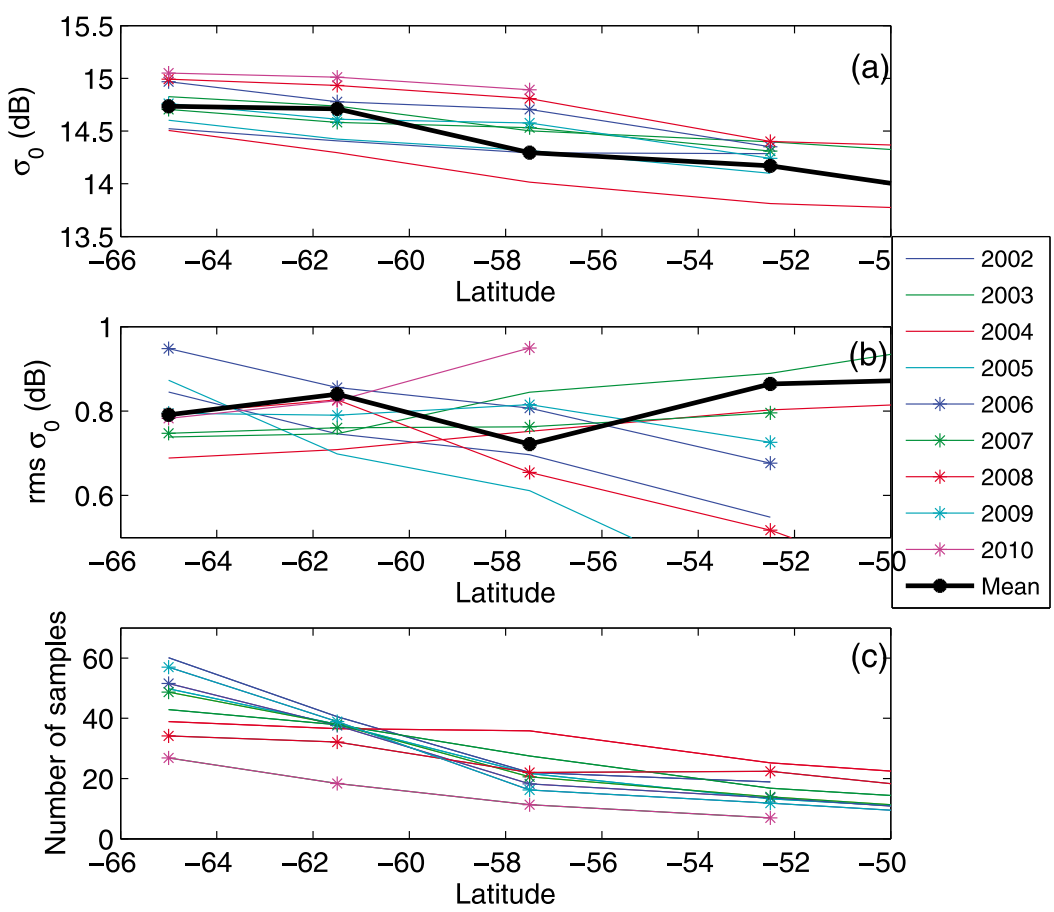

Figure 1. (a) Mean value and (b) standard deviation of the $2 \%$ of the highest $\sigma_{i c e b}$, as a function of year and latitude, and (c) number of samples per bins.

the hypothesis of constant surface backscatter of iceberg. The mean value and standard deviation of $2 \%$ of the highest values, robust estimators [Horn, 1990] of the sample maximum, are thus used to analyze the maximum $\sigma_{i c e b}$ and its variability. Figure 1 presents the variation of the maximum $\sigma_{i c e b}$ as a function of latitude and year as well as the standard deviation and the number of samples in each latitudeyear class. The latitude bins were chosen to equalize as far as possible the number of samples per bins (see Figure 1c). The maximum and standard deviation (std) computed for the nine year period are also presented in the figure. Bins containing less than 10 samples were not considered. The maximum value decreases slightly with latitude between 65 and $50^{\circ} \mathrm{S}$ (by -0.3 to $-0.8 \mathrm{~dB}$ depending on the year) and this meridional variation reflects, at least partly, the mean decrease in iceberg area with latitude. The interannual variability in each latitude bin ranges from $0.5 \mathrm{~dB}$ to $0.81 \mathrm{~dB}$ while the std remains stable around $0.8 \mathrm{~dB}$. Very similar results were found on the zonal variability (figure not presented here). The maximum $\sigma_{i c e b}$ appears thus quite stable, especially when considering the variability of iceberg distribution as well as the noise level on altimeter backscatter measurement (about $0.5 \mathrm{~dB}$ ). The hypothesis of a constant iceberg surface backscatter coefficient can be thus be considered as valid as in a first order approximation.

[10] To our knowledge, no studies have been published on the Ku-band quasi-specular backscatter of small icebergs. However, studies have been published on the analysis of Envisat Ku-band backscatter over ice caps [Legrésy et al., 2005; Tran et al., 2008, 2009]. Over flat surfaces such as central Greenland or the Droning Maud Land, the Ku-band surface backscatter is in the order of 15-16 dB. Using this value for iceberg surface backscatter and $+2.9 \mathrm{~dB}$ inter- calibration correction between the Envisat and Jason-1 Ku band backscatter coefficient estimated by Faugère et al. [2006], the iceberg surface backscatter $\sigma_{1}$ is set at $19 \mathrm{~dB}$.

[11] Secondly, it is necessary to fix either a mean distance from nadir of the icebergs or a mean iceberg freeboard elevation. As the distance from nadir is a purely random variable with uniform probability and as it has a stronger impact on backscatter than the freeboard elevation [Tournadre et al., 2008], we choose to assume a constant freeboard elevation. Following Gladstone et al. [2001] the freeboard elevation for icebergs larger than $200 \mathrm{~m}$, is set at $28 \mathrm{~m}$ corresponding to a mean iceberg thickness of $250 \mathrm{~m}$ (using Dowdeswell and Bamber's [2007] formula for summer). This freeboard corresponds to the average freeboard over the iceberg and is lower than the values proposed by Romanov et al. [2011] for icebergs of different shapes but corresponds to an average freeboard over the iceberg and not the iceberg maximum visible vertical dimension as obtained from ship observations.

[12] Using the fixed freeboard and surface backscatter assumptions, the analytical model of waveforms presented by Tournadre et al. [2008] (see equation (A3)) is used to compute the signature of icebergs as a function of distance from nadir, (0 to $12 \mathrm{~km})$, and area $\left(0.01\right.$ to $\left.9 \mathrm{~km}^{2}\right)$. For simplicity, icebergs are assumed square. The time of the echo $t_{e c h}=f(d, A)$ and the mean backscatter $\sigma_{\text {iceb }}=g(d, A)$ are estimated from the modeled waveforms and are then used to compute the inverse model $A=l\left(t_{\text {ech }}, \sigma_{i c e b}\right)$ and $d=m\left(t_{e c h}, \sigma_{\text {iceb }}\right)$ presented in Figure 2. The results of the waveform modeling shows a saturation of $\sigma_{\text {iceb }}$ around $15 \mathrm{~dB}$ for icebergs larger than $\sim 8 \mathrm{~km}^{2}$. The difference between the maximum backscatter and the surface backscatter results from the fact that $28 \mathrm{~m}$ freeboard icebergs can only be detected off nadir $(d>5 \mathrm{~km})$ which introduces an 
(a)

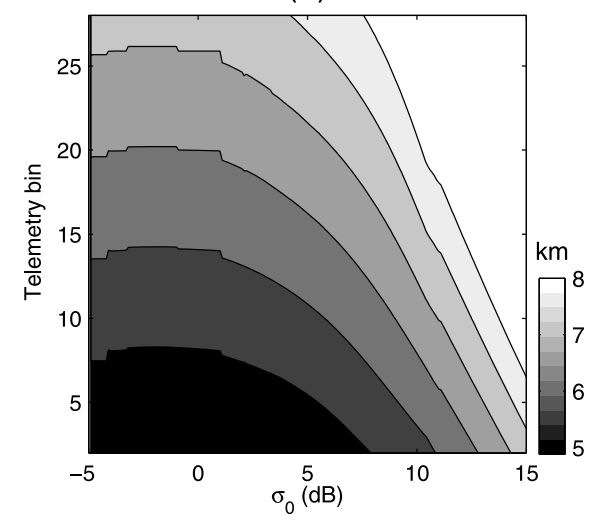

(b)

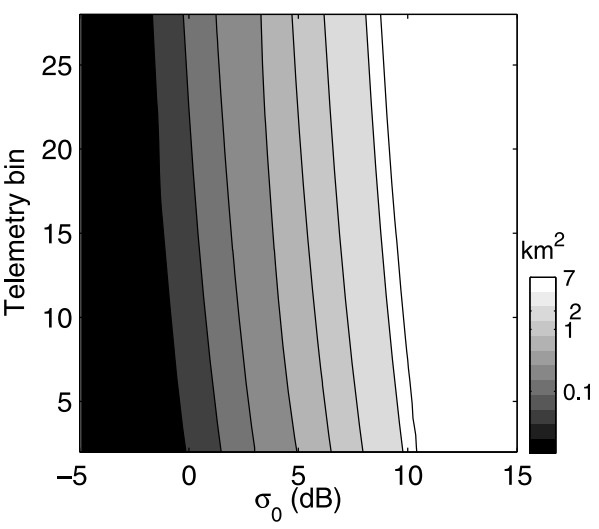

Figure 2. Model used to invert the position of the echo and the iceberg backscatter in terms of (a) distance of the iceberg center from nadir and (b) area for $28 \mathrm{~m}$ freeboard elevation icebergs with a $19 \mathrm{~dB}$ ice backscatter coefficient(log scale).

attenuation of the signal due to the antenna beam pattern and the surface sampling geometry of the altimeter (see Appendix A). This maximum value of $15 \mathrm{~dB}$ is close to the observed mean value of the maximum backscatter and corroborates the choice of $\sigma_{0}^{i c e}$.

[13] The inverse model is applied to the range and backscatter of the detected icebergs to estimate the area and distance from nadir. Figure 3 presents the rescaled frequency histogram, (i.e., an estimator of the probability density function) of the areas. As suggested by Wadhams [1988] for iceberg length, the area distribution follows quite well a twoparameter lognormal distribution $f_{X}$ of the form

$$
f_{X}(x ; \mu, \sigma)=\frac{1}{x \sigma \sqrt{2 \pi}} e^{-\frac{(\ln x-\mu)^{2}}{2 \sigma^{2}}}, \quad x>0,
$$

where $\mu$ and $\sigma$ are the location and scale parameters respectively. The Maximum Likelihood Estimations (MLE) (see for example Wilks [2006] for the estimation method) of $\mu$ and $\sigma^{2}$ at a $99 \%$ confidence level are respectively 12.26 and 1.56. The mean of the distribution, defined by $e^{\mu+\frac{\sigma^{2}}{2}}$, is $7.3310^{5} \mathrm{~m}=0.733 \mathrm{~km}^{2}$. As most past studies published on the size of iceberg were based on the analysis of ship borne data and they analyzed the apparent diameter [Wadhams, 1988] or the maximum horizontal dimension at the waterline [Romanov et al., 2011], the histogram of the iceberg length (i.e., $\sqrt{A}$ ) is also computed and a lognormal distribution fitted to the data. The MLE of $\mu$ and $\sigma^{2}$ at a $99 \%$ confidence level for the iceberg length are respectively 6.14 and 0.61 corresponding to a mean length of $630 \mathrm{~m}$.

[14] This value is within the range of mean length values given by Romanov et al. [2011] for different shapes of iceberg (from $188 \mathrm{~m}$ for pinnacle icebergs to $941 \mathrm{~m}$ for tabular ones) in the southern ocean. It is larger than the value of $516 \mathrm{~m}$ provided by Wadhams $[1988]\left(\mu=6.04 \sigma^{2}=0.413\right)$ or the all shape mean of $471 \mathrm{~m}$ provided by Romanov et al. [2011]. These mean value differences result, at least in part, from the fact that an altimeter can only detect icebergs larger than $\sim 100 \mathrm{~m}$ while ship-borne radars used by Wadhams [1988] or Romanov et al. [2011] can detect icebergs larger than $20-50 \mathrm{~m}$.

[15] As the method of estimation of iceberg size strongly depends on the assumptions made on the iceberg freeboard and backscatter it is necessary to analyze its sensitivity to a

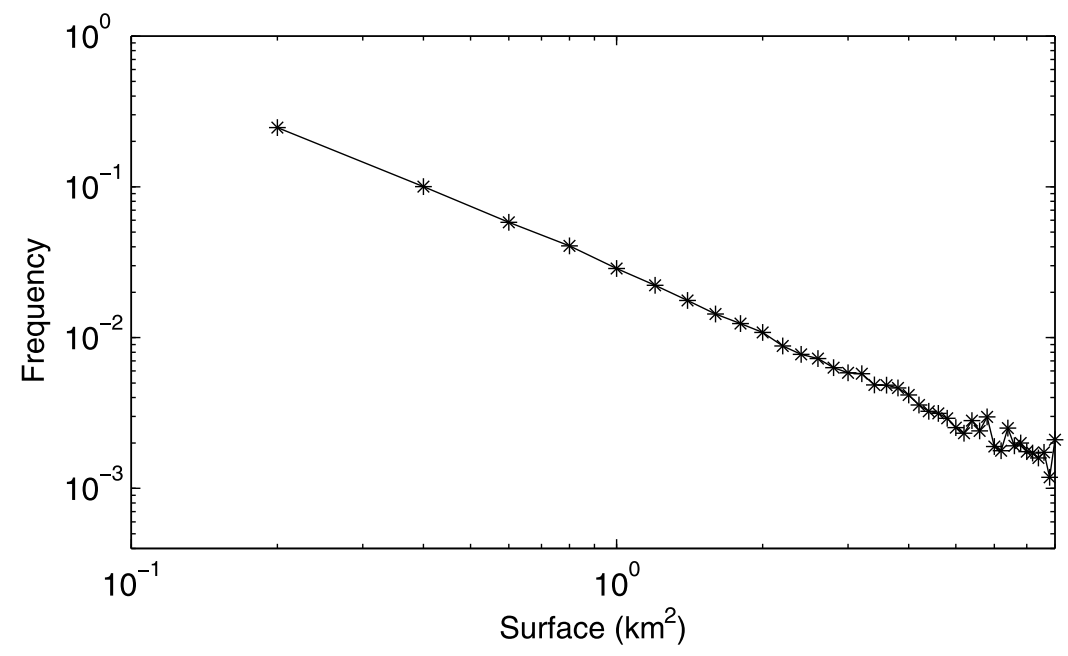

Figure 3. Rescaled histogram (density function) of the small iceberg area (logarithm scale). 
Table 1. Maximum Likelihood Estimates, at a $99 \%$ Confidence Level, of the Location $\mu$ and Scale $\sigma^{2}$ Parameters of the Lognormal Distributions Fitted to the Area Distributions and Mean Area for Different Input Parameters, Freeboard and Surface Backscatter, of the Inversion Model

\begin{tabular}{ccccc}
\hline $\begin{array}{c}\text { Freeboard } \\
(\mathrm{m})\end{array}$ & $\begin{array}{c}\text { Ice Backscatter } \\
(\mathrm{dB})\end{array}$ & $\mu$ & $\sigma^{2}$ & $\begin{array}{c}\text { Mean } \\
\text { Area }\left(\mathrm{km}^{2}\right)\end{array}$ \\
\hline 23 & 19 & 12.12 & 1.58 & 0.64 \\
28 & 19 & 12.28 & 1.56 & 0.73 \\
33 & 19 & 12.40 & 1.54 & 0.80 \\
28 & 18 & 12.60 & 1.49 & 0.91 \\
28 & 19 & 12.28 & 1.56 & 0.73 \\
28 & 20 & 11.99 & 1.60 & 0.58 \\
\hline
\end{tabular}

modification of input parameters, i.e., to test its robustness. This analysis can also provide a first estimate of the size uncertainty. Inverse models have thus been computed for 23 and $33 \mathrm{~m}$ freeboard and constant ice backscatter of $19 \mathrm{~dB}$ and for constant freeboard of $28 \mathrm{~m}$ and ice backscatter of 18 and $20 \mathrm{~dB}$. The chosen ice backscatter limit of $\pm 1 \mathrm{~dB}$ corresponds to the standard deviation of the observed iceberg maximum backscatter south of $60^{\circ} \mathrm{S}$ and the $\pm 5 \mathrm{~m}$ freeboard variations corresponds to the variation of the mean freeboard (for all shape of iceberg) in the different sections of the southern ocean presented by Romanov et al. [2011] (see their Table VI).

[16] Table 1 summarizes the MLE (at a 99\% confidence level) of the location $\mu$ and scale $\sigma^{2}$ parameters of the lognormal distributions fitted to area distributions as well as the mean area for different model input parameters. The scale parameter $\sigma$ varies only weakly with input parameters and change of location $(\mu)$ corresponds to a translation of distribution along the $\ln (A)$ axis. The relative size of icebergs is only weakly sensitive to model parameters. The results show that the impact of freeboard changes on the mean area is weaker ( $\pm 14 \%$ for a $\pm 20 \%$ variation of freeboard) than that of backscatter $( \pm 25 \%$ for a $\pm 26 \%$ variation of linear backscatter). The method thus appears quite robust and the impact of input parameters is almost linear.

\subsubsection{Volume of Ice}

[17] The iceberg data set is then used to compute the monthly probability of presence $P(i, j, t)$ ( $t$ being the month), over a regular polar stereographic grid $(i, j)$ using relation (1) as well as the mean monthly iceberg area, $A(i, j, t)$ defined as

$$
A(i, j, t)=\frac{1}{N(i, j, t)} \sum_{k=1}^{N(i, j, t)} a_{k},
$$

where $a_{k}$ are the areas of the $N(i, j, t)$ icebergs detected within the grid cell $(i, j)$ during month $t$.

[18] The total area of the iceberg detected within a grid cell $(i, j)$ is simply

$$
S(i, j, t)=\sum_{k=1}^{N(i, j, t)} a_{k}
$$

and as the iceberg thickness $H_{T}$ is assumed constant, the detected volume of ice is $S(i, j, t) H_{T}$.
[19] The detected volume of ice per unit area of the grid cell is the ratio of the detected volume of ice to the total area sampled by the altimeter over month $t$, i.e., $S(i, j, t) H_{T} /$ $\left(A_{S W} N_{S}(i, j, t)\right)$ where $A_{S W}$ is the area of an altimeter footprint and $N_{s}(i, j, t)$ is the number of valid altimeter samples. Assuming that the monthly spatial distribution of iceberg within a grid cell is uniform, the total volume of ice within the grid cell is the product of the volume per unit area by the area of the grid cell, i.e.,

$$
V(i, j, t)=\frac{S(i, j, t) H_{T}}{A_{S W} N_{S}(i, j, t)} \Delta x \Delta y .
$$

The area of the altimeter footprint for the detection of $28 \mathrm{~m}$ freeboard icebergs $A_{S W}$ is the product of the altimeter along track resolution $(290 \mathrm{~m})$ by the range of distance from nadir over which an iceberg can be detected. Using the relationship between the time of the echo, the distance from nadir and the elevation of a target emerging from the sea given by Tournadre et al. [2008], the range of detection of an iceberg is given by

$$
\sqrt{\left(c t_{0}+2 h\right) H^{\prime \prime}}+\frac{\bar{d}_{0}}{2} \geq d \geq \sqrt{\left(c t_{1}+2 h\right) H^{\prime \prime}}-\frac{\bar{d}_{0}}{2},
$$

where $H^{\prime \prime}=H /(1+H / a)$ is the reduced satellite altitude, $a$ being the earth's radius and $H$ the satellite altitude, $h$ is the iceberg freeboard elevation, $c$ is the speed of light, $d_{0}$ is the mean iceberg length, and $t_{0}$ and $t_{1}$ are the time limits of the noise range part of the waveform. For Jason-1, $H=1340 \mathrm{~km}$ and $t_{0}=-32 \times 3.125 \mathrm{~ns}$ and $t_{1}=-2 \times 3.125 \mathrm{~ns}$, then $8.24 \mathrm{~km}>d>4.85 \mathrm{~km}$, thus $A_{S W} \simeq 5.8 \times 3.5 \times 2 \mathrm{~km}^{2}$, where factor 2 accounts for the left-right ambiguity of detection.

[20] The lack of in situ data prevents direct validation of the volume of ice of small icebergs and estimate of the uncertainties inherent to the method. In particular, those related to the detection capability of the altimeter which depends on the sensitivity of the instrument and its signal-tonoise ratio which can lead to an underestimation of the number of icebergs. However, the results of the robustness tests show that the relative size of the icebergs are weakly sensitive to model input parameters and furthermore the errors inherent to the method are identical whatever the zone or the time. The relative variations in time and space of the inferred volume of ice will thus be meaningful even if the absolute values may present quite large uncertainties.

\section{Iceberg Distribution}

\subsection{Overall Mean}

[21] Figure 4 presents the 9 year mean probability of presence $(P)$ of icebergs, mean iceberg length $\left(d_{0}\right)$ and mean monthly volume of ice $(V)$ over the southern ocean estimated over a regular polar stereographic grid of $100 \mathrm{~km}$ resolution. The mean length is computed by fitting a lognormal distribution to the length histogram for each grid cell. The mean volume of ice is represented only for values larger than $0.01 \mathrm{Gt} / \mathrm{month}\left(1 \mathrm{Gt}=10^{9} \mathrm{~m}^{3}\right)$. The minimum and maximum sea ice extent for the period estimated from the weekly AMSR-E sea ice data from the University of 
(a)

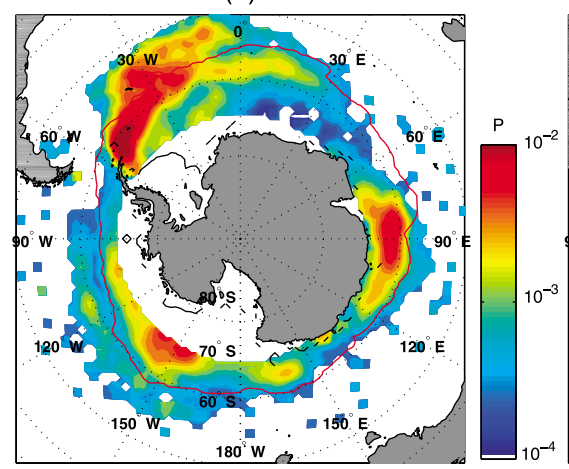

(b)

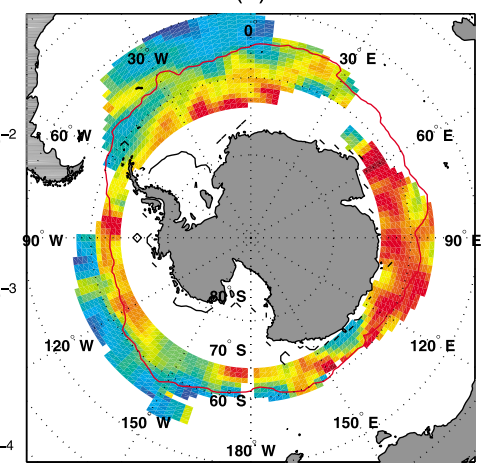

(c)

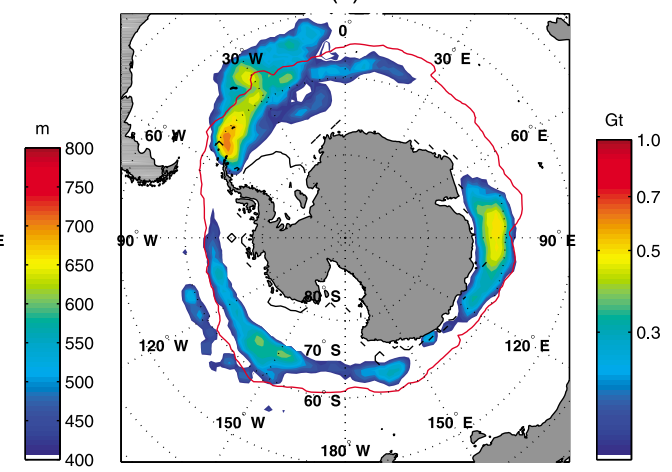

Figure 4. (a) Average probability of icebergs from 2002 to 2010, (b) mean iceberg length (in m), (c) mean iceberg volume (in Gt.month ${ }^{-1}$ or $\mathrm{km}^{3} \cdot \mathrm{month}^{-1}$ ). The black and red solid lines indicate the minimum and maximum sea ice extent from the AMSR-E sea ice data.

Bremen [Spreen et al., 2008] have also been represented in the figure.

[22] The northernmost limit of the detected icebergs is in good agreement in all regions with northernmost limits from visual observations [Soviet Antarctic Survey, 1966; Tchernia and Jeannin, 1984] or iceberg trajectory modeling [Gladstone et al., 2001] and with the previous results by Tournadre et al. [2008]. The patterns of the distribution with three well-defined maxima, one in each ocean corresponds to general iceberg circulation in the Southern Ocean as described for example by Gladstone et al. [2001]. The largest maximum concentration of icebergs is found in the Southern Atlantic (SA) ocean where the zone of high concentration $\left(>0.510^{-2}\right)$ extends from Graham Land to the west to almost $0^{\circ}$ of longitude to the east while the zone of lower concentration $\left(>0.510^{-3}\right)$ sits around $30^{\circ} \mathrm{E}$. In the area between $10^{\circ} \mathrm{W}$ and $40^{\circ} \mathrm{E}$ the present study is missing coverage because while the Jason coverage limit is at $66^{\circ} \mathrm{S}$, the coast in this region is nearer $70^{\circ} \mathrm{S}$. Young [1998] observed that icebergs transit near the coast in this area. The high concentration of icebergs extends much further north than the maximum sea ice limit and reaches $50^{\circ} \mathrm{S}$ between $40^{\circ} \mathrm{W}$ to $30^{\circ}$ E. East of the Southern Georgia and the South Sandwich islands, the distribution divides into two main iceberg paths. The weaker one along $58^{\circ}-59^{\circ} \mathrm{S}$ suggests a recirculation of icebergs within the eastern branch of the Weddell Gyre along the Antarctic continent [Klatt et al., 2005], while the stronger one, located on a more northerly path along $53^{\circ} \mathrm{S}$, corresponds to a north-eastward iceberg transport by the Antarctic Circumpolar Current. The presence of a weaker concentration near $20^{\circ} \mathrm{W}$ confirms the observations of Schodlok et al. [2006] that the general iceberg drift in the Wedell Sea presents two distinctive patterns, one to the west of $40^{\circ} \mathrm{W}$ where the icebergs drift close to the Antarctic Peninsula and a second weaker one, east of $40^{\circ} \mathrm{W}$, corresponding to iceberg drifting in the central and eastern Wedell Sea.

[23] The distribution of the second maximum concentration of icebergs located in the Southern Indian (SI) sector concords with the results of previous studies by Romanov et al. [2008] or Jacka and Giles [2007] based on shipborne observations. It extends from the Enderby land in the west $\left(\sim 60^{\circ} \mathrm{E}\right)$ to the Mertz Glacier in the east $\left(\sim 145^{\circ} \mathrm{E}\right)$. The maximum concentration is found between $65^{\circ} \mathrm{E}$ and $120^{\circ} \mathrm{E}$ and results from the calving from Amery, Schakleton and West Ice shelves and from the westward drifts of the icebergs in the coastal current [Romanov et al., 2008]. Between $85^{\circ} \mathrm{E}$ and $115^{\circ} \mathrm{E}$ the distribution of icebergs extends up to $60^{\circ} \mathrm{S}$ resulting from ocean circulation over the Kerguelen Plateau. It is worth noting that the altimeter also clearly reveals a peak of iceberg concentration north of the Mertz and Ninnis glaciers revealing the production of icebergs in this area, both likely calved from the Cook ice shelf, Ninnis and Mertz glaciers and from icebergs transiting from the Ross Sea.

[24] In the Southern Pacific (SP) Ocean, iceberg concentration is significantly lower than that in the SI and SA. This is partly due to the limitation of Jason observations at $66^{\circ} \mathrm{S}$. Most icebergs in this area are likely produced south of $70^{\circ} \mathrm{S}$. The concentration is maximal off the Ross Sea near $150^{\circ} \mathrm{W}$ and decreases eastward up to the Ostrov Petra Island at $90^{\circ} \mathrm{W}$. A secondary maximum is observed near the Balleny islands (near $163^{\circ} \mathrm{E}$ ) and corresponds to icebergs drifting along the Victoria land coast and exiting the Ross Sea around Cap Adare then turning around the Balleny Islands [Keys and Fowler, 1989; Glasby, 1990]. North of the maximum sea ice extent, the iceberg concentration is low but still significant showing that some icebergs travel north and are then caught in the Antarctic Circumpolar Current and carried east as far as $90^{\circ} \mathrm{W}$ around $60^{\circ} \mathrm{S}$. The general patterns of the distribution concord with results of iceberg trajectory modeling of Gladstone et al. [2001].

[25] The decrease in mean iceberg length from $\sim 700 \mathrm{~m}$ near $60^{\circ} \mathrm{S}$ to $\sim 400 \mathrm{~m}$ near $55^{\circ}-50^{\circ} \mathrm{S}$ clearly shows the melting and deterioration of icebergs in their northward path in the SA and SP oceans (see Figure 4b). The icebergs of the SI ocean are significantly larger and the largest ones are observed near the Enderby Land $\left(60^{\circ} \mathrm{W}\right)$ and the Amery ice shelf $\left(70^{\circ} \mathrm{W}\right)$. The size difference can be explained by the more northern location of the calving zones in the SI and by a more rapid re-trapping of the icebergs by sea ice which limits their open water travel and their deterioration.

[26] The distribution of the mean volume of ice (see Figure 4c) clearly shows that the SA contributes to the major part of the ice. The icebergs originating from the Antarctic Peninsula are transported north-east-wards conveying fresh water deep into the SA up to $50^{\circ} \mathrm{S}$ and $0^{\circ} \mathrm{E}$ much further 


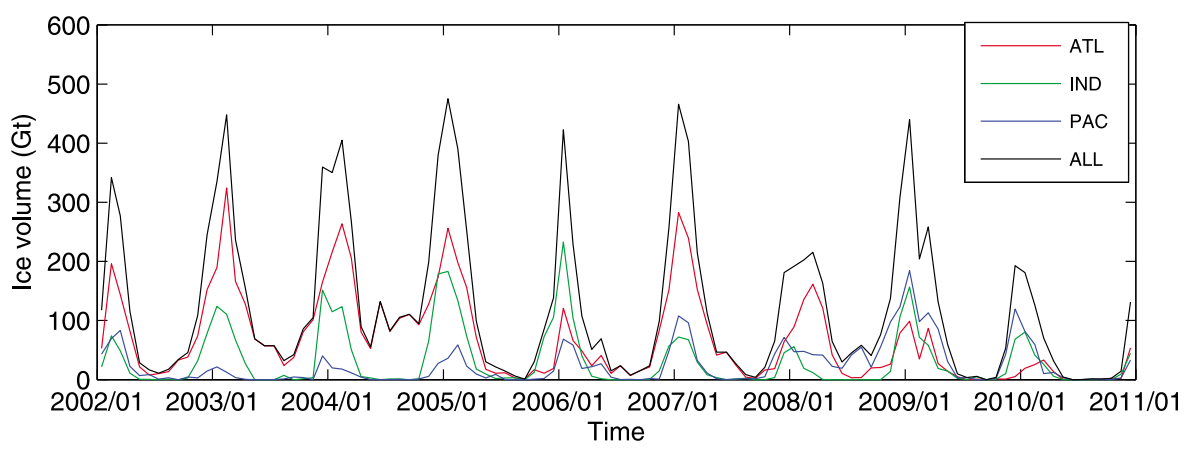

Figure 5. Monthly iceberg volume in open water for the southern ocean (black line), the south Atlantic ocean (red line), the south Indian ocean (green line) and the south Pacific ocean (blue line), in Gt or $10^{9} \mathrm{~m}^{3}$.

north than the maximum sea ice extent. In the SI, the ice is mainly concentrated south of $60^{\circ} \mathrm{S}$ between $70^{\circ} \mathrm{W}$ and $100^{\circ} \mathrm{W}$ and very little ice is transported north of the maximum sea ice extent. In the observable part of the SP, the volume of ice is small with some transport north of the maximum sea ice extent.

\subsection{Time Variability}

[27] The monthly iceberg ice volume, detected in open water for the southern ocean, the SA (from $70^{\circ} \mathrm{W}$ to $30^{\circ} \mathrm{E}$ ), the SI (from $30^{\circ} \mathrm{E}$ to $150^{\circ} \mathrm{E}$ ) and the SP (from $150^{\circ} \mathrm{E}$ to $70^{\circ} \mathrm{W}$ ), is presented in Figure 5. The time series present, as expected, a strong seasonal cycle with maxima during the austral summer and minima during the austral winter. In the period 2002-2010, the mean annual maximum volume of ice north of $67^{\circ} \mathrm{S}$ is about $400 \mathrm{Gt}$, which represents about $35 \%$ of the mean annual mass of larger tabular icebergs (icebergs larger than $18.5 \mathrm{~km}$ in length), $1089 \pm 300 \mathrm{Gt}$, calving from Antarctica given by Silva et al. [2006]. The volumes of ice computed using the different inversion models presented in section 2.2.1 are used to estimate the uncertainty of the volume estimate. The minimum and maximum monthly volumes are presented in Figure 6. For significant volumes (i.e., larger than $50 \mathrm{Gt}$ ), the uncertainty is $26 \%$, i.e., $104 \mathrm{Gt}$ for a total of $400 \mathrm{Gt}$. This error is of the same order of magnitude as the uncertainty on the mass of larger tabular icebergs [Silva et al., 2006]. Smaller icebergs can thus play a significant role in the distribution of fresh water and they should be taken into account when studying the injection of meltwater in the southern ocean. The seasonal cycle exhibits a very large inter-annual variability: the summer maximum can vary by more than a factor 2 , from $250 \mathrm{Gt}$ in 2008 and 2010 to almost $550 \mathrm{Gt}$ in 2005 and 2009 while the winter minimum, in general almost negligible, reaches $150 \mathrm{Gt}$ in 2004 . These overall seasonal and interannual variations reflect much contrasted situations for the three oceans. The volume of ice in the SA represents in general more than $50 \%$ of the total volume but can be as high as $80 \%$ in 2003 or 2008 or as low as $20-15 \%$ in 2006 , 2009 or 2010 . The total volume is in general of the order of $200 \mathrm{Gt}$ but can decrease to as low as $50 \mathrm{Gt}$ in 2006 or 2010. The same high variability of the volume of ice is observed in the SI and SP oceans with no correlation between the three basin contents.

[28] The mean length presented in Figure 7 also exhibits a very clear seasonal cycle with higher values in austral summer and lower ones in winter. After a peak value in January in the order of $750 \mathrm{~m}$, the mean length steadily decreases during summer to a low of about $450 \mathrm{~m}$ in winter, reflecting the melting and deterioration of icebergs during their travel in open water away from sea ice. The overall mean variation in length between January and May is almost linear and a linear best fit of the data gives a rate of length decay of 1.5 m.day ${ }^{-1}$ which is in the same order of magnitude as the melting rate given by Jacka and Giles [2007] for 400 to $800 \mathrm{~m}$ icebergs (see their Table 3 ).

[29] The mean annual volume of ice from 2002 to 2010 presented in Figure 8 is characterized by a very large inter-

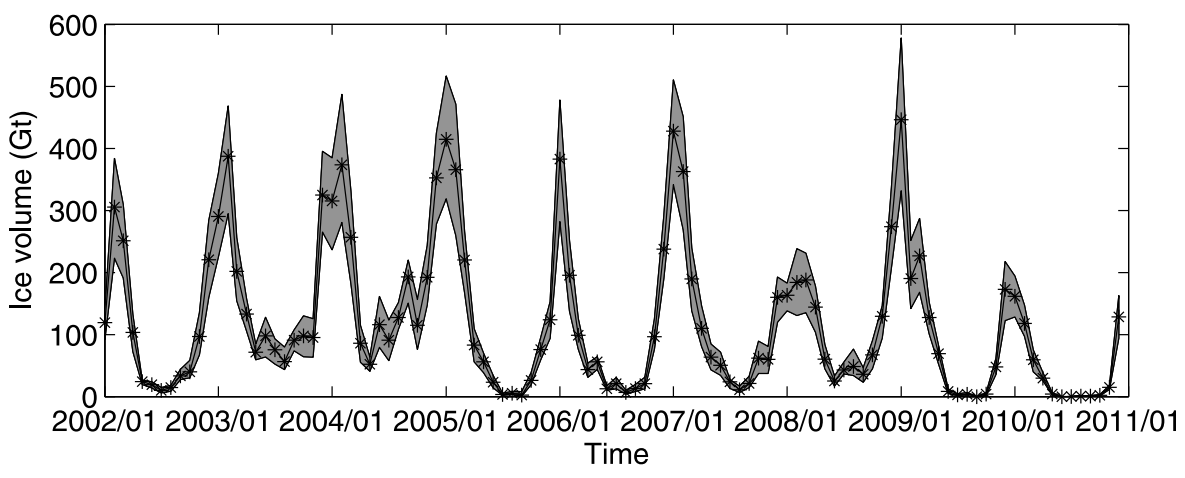

Figure 6. Minimum and maximum volume of ice in the southern ocean (in Gt) estimated using the different inversion models. 


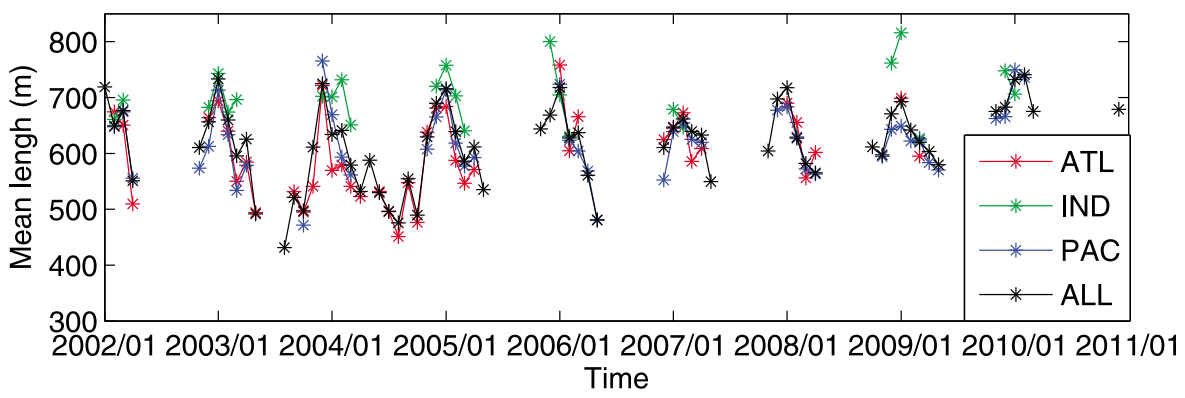

Figure 7. Monthly mean iceberg length from the lognormal fit of the length distribution for the southern ocean (black line), the South Atlantic Ocean (red line), the south Indian Ocean (green line) and the South Pacific Ocean (blue line).

annual variability, spatial as well as temporal, in the three oceans. The transport of ice north of the maximum sea ice extent is extremely variable in the SA and the SP with significant amount in 2003, 2004, 2007 and 2008 in the SA and in 2008 and 2009 in the SP, which indicates that a large number of icebergs reached the Antarctic Circumpolar Current (ACC) and are transported eastward. Some other years, very few icebergs travel north of $58^{\circ} \mathrm{S}$ and they remain mainly confined within the Wedell Gyre in the SA and within the Ross Gyre in the SP. In the SI, although the zone of maximum varies little, the concentration presents large inter-annual variability especially near the Amery and West shelves which are the main zones of iceberg calving.

\subsection{Spatiotemporal Variability}

[30] The time-latitude and time-longitude Hovmüller diagrams of the monthly volume of ice constitutes another way to apprehend the spatiotemporal variability of icebergs and

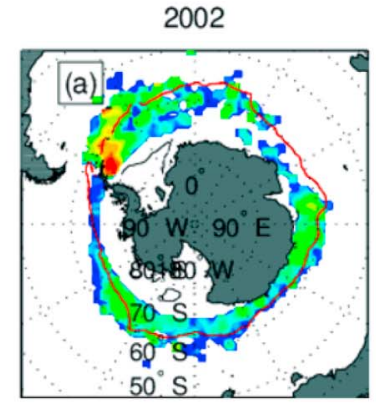

2005

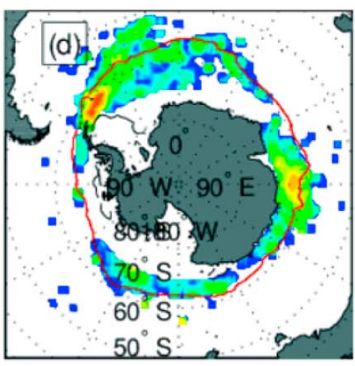

2008

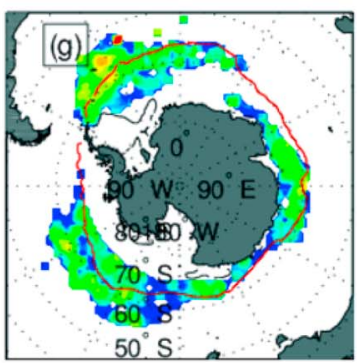

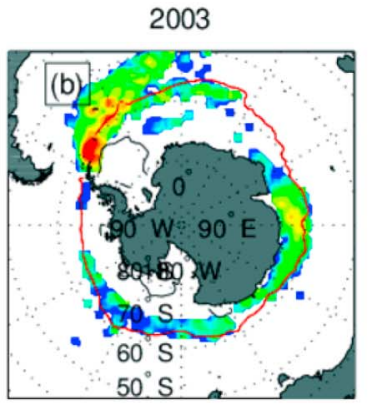

2006

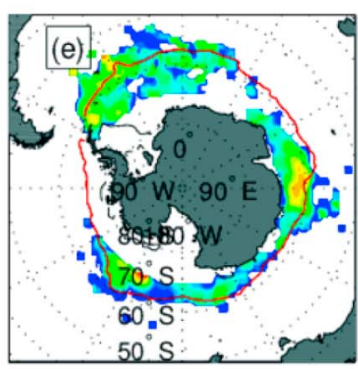

2009

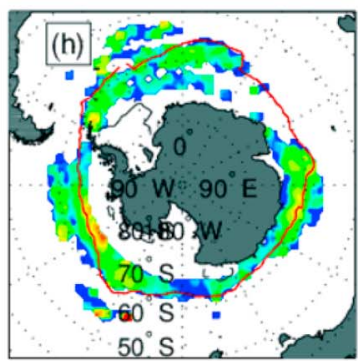

2004

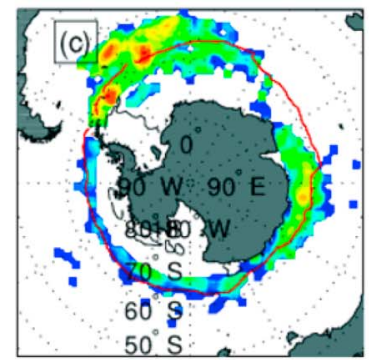

Gt

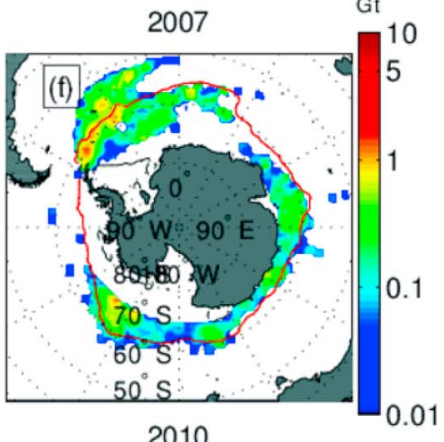

2010

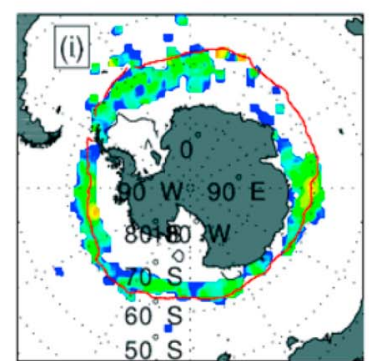

Figure 8. Mean annual iceberg volume from 2002 to 2010. The color scale is logarithmic. Solid red and black lines represent respectively the maximal and minimal sea ice extent from AMSR-E sea ice data. 


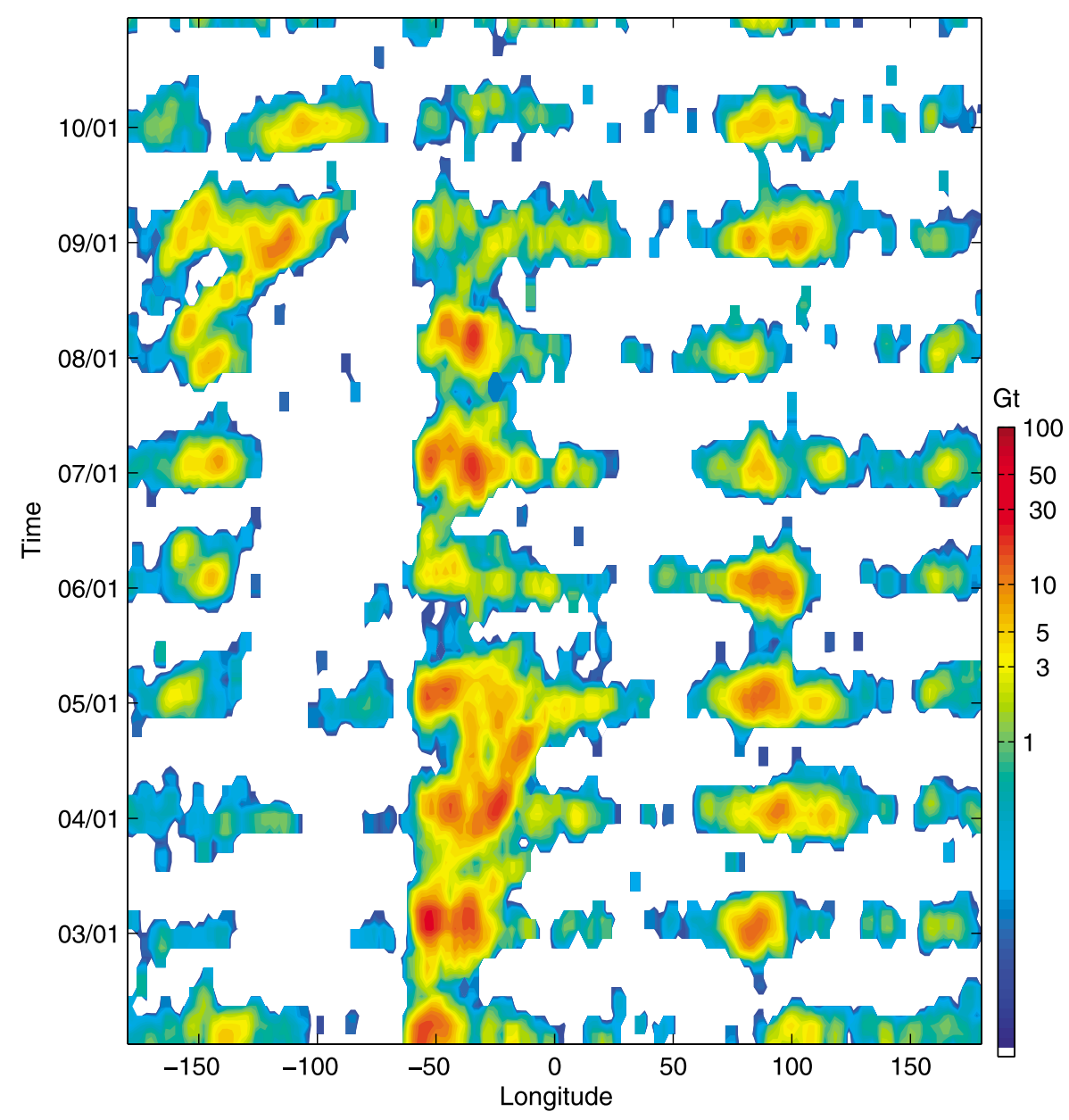

Figure 9. Longitude-time Hovmüller diagram of the monthly volume of ice integrated from $66^{\circ} \mathrm{S}$ to $50^{\circ} \mathrm{S}$. The color scale is logarithmic.

they can be used to analyze the transport of ice. The timelongitude diagram of the volume of ice integrated between $66^{\circ} \mathrm{S}$ and $45^{\circ} \mathrm{S}$ presented in Figure 9 reveals the release of icebergs trapped in sea ice at the beginning of the austral summer in December-January. The position of the zone of release, as well as the volume of ice, are highly variable in the three basins. For example, in the SI $\left(50\right.$ to $\left.150^{\circ} \mathrm{W}\right)$, this zone covers 83 degrees of longitude (from $47^{\circ} \mathrm{W}$ to $120^{\circ} \mathrm{W}$ ) with a maximum of $20 \mathrm{Gt}$ in 2003 and reduces about 40 degrees (from $70^{\circ} \mathrm{W}$ to $110^{\circ} \mathrm{W}$ ) in 2010 with a maximum of 4 Gt. Some regions like the Bellinghausen Sea $\left(\sim 90^{\circ} \mathrm{W}\right)$, are characterized by small sporadic bursts of icebergs (in 2005). The overall pattern of the distribution reveals a general eastward propagation of icebergs in the three basins. This propagation is particularly visible when icebergs are present in open water during winter and thus travel quite far north within the ACC or the Wedell or Ross Gyres, such as in 2003 to 2005 in the SA or in 2008-2009 in the SP. For these years, the eastward transport appears significantly faster in the SP than that in the SA.

[31] The time-latitude Hovmüller diagram of the monthly volume of ice in the three ocean basins, presented in Figure 10, confirms the complexity and high variability of iceberg distribution. Except in the SI and SP oceans, icebergs are present only sporadically in open water in winter.
In the SA, large amounts of ice are not re-trapped by sea ice and can travel north, as far as $45^{\circ} \mathrm{N}$ (in 2003 and 2004). During the austral summer, the apparent southward transport of ice reflects the southwards retreat of sea ice that frees trapped icebergs. In the SA, large amounts of ice are advected to the north especially in 2003, 2004 and 2007. This northward advection is in general quite limited in the two other ocean basins except sporadically like in 2008 2009 in the SP and 2005-2006 in the SI.

\section{Relation With Large Icebergs}

[32] Although small icebergs calve from the Antarctic continent glaciers or are released by sea ice, a large proportion of those detected in open water results from the deterioration of large icebergs, mainly tabular ones. This calving of smaller icebergs from large ones can be clearly seen on many satellite visible images and it is also manifest in Figure 11 that presents the trajectory of the C19a tabular iceberg and the number of coincident small icebergs in its vicinity. The $\mathrm{C} 19 \mathrm{a}$ track comes from the Brigham Young University Antarctic iceberg data base, which provides the location of icebergs larger than $5-6 \mathrm{~km}$ in length [Stuart and Long, 2011b]. C19a was chosen because once released from sea ice in January 2008 it 
(a)

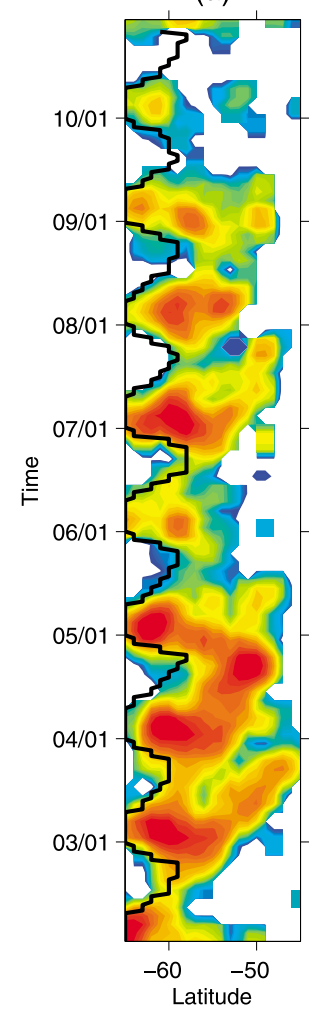

(b)

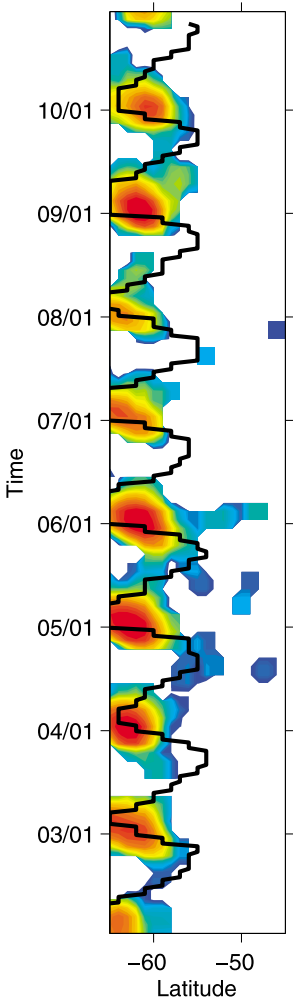

(c)

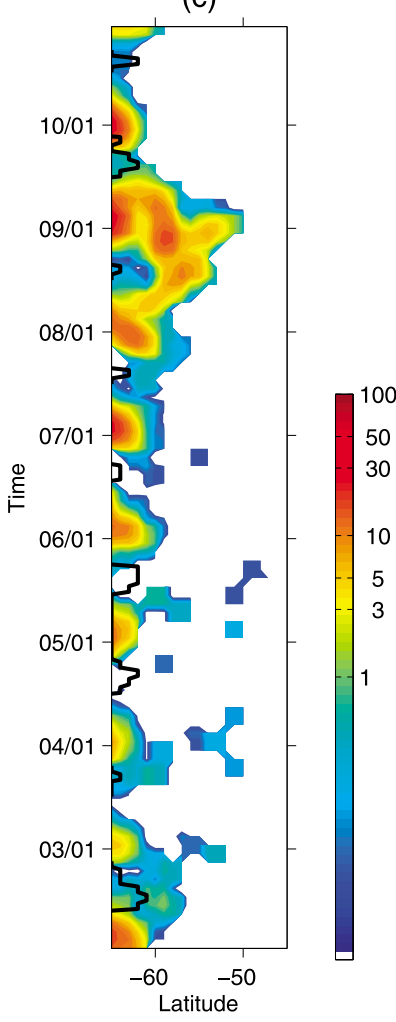

Figure 10. Time-latitude Hovmüller diagram of the monthly volume of ice (in Gt) for (a) the South Atlantic Ocean (from $70^{\circ} \mathrm{W}$ to $30^{\circ} \mathrm{E}$ ), (b) the South Indian Ocean (from $30^{\circ} \mathrm{E}$ to $150^{\circ} \mathrm{E}$ ) and (c) the South Pacific Ocean (from $150^{\circ} \mathrm{E}$ to $70^{\circ} \mathrm{W}$ ). The thick black line represents the maximum latitude of the sea ice extent within the basin estimated from the AMSR-E sea ice data. The color scale is logarithmic.

follows a solitary course for more than a year in the South Pacific Ocean making it easier to demonstrate its relation with small icebergs. From January 2008 to April 2009, small icebergs constantly calve and drift away from $\mathrm{C} 19 \mathrm{a}$ at a rate of 1 to 20 every 10 days with peak values in May and November 2008 and March 2009. The observed variations of the deterioration process depend on environmental parameters, such as sea state, whose analysis is beyond the scope of the present study but could be investigated in the future.

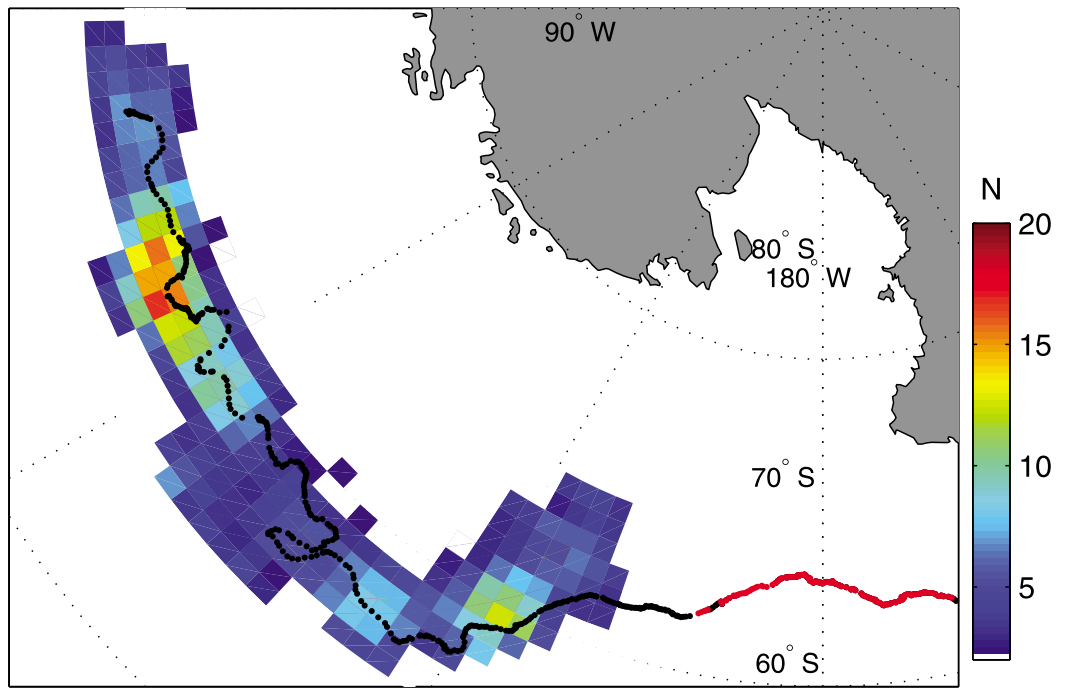

Figure 11. Number of small icebergs detected along the trajectory of the C19a tabular iceberg from Brigham Young University Antarctic iceberg data base in 2008-2009. The red line indicates the C19a trajectory in sea ice and the black line in open water. 


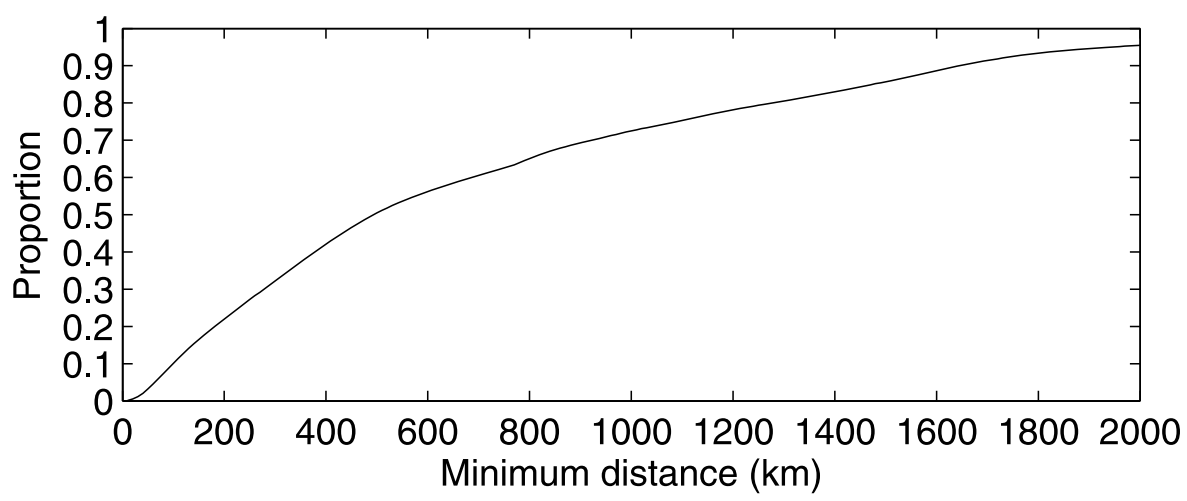

Figure 12. Proportion of the detected small icebergs closer than a given distance to the closest large iceberg.

[33] Using the B.Y.U data base, the distance between small icebergs and the nearest coincident large iceberg $(>5 \mathrm{~km}$ in length) was computed. The cumulative probability of the distance, presented in Figure 12, shows that only 22\% of small icebergs are within $200 \mathrm{~km}$ from a large one and that $50 \%$ are distanced at more than $500 \mathrm{~km}$. The geographical distribution of the proportion of small icebergs closer than $200 \mathrm{~km}$ to a large one as well as the mean distance, presented in Figure 13, reveals two distinct regimes in the relationship between small and large icebergs. The first one found in the Scotia Sea (between the Antarctic Peninsula and the South Georgia Island), along the Antarctic coast in the SI ocean, and in the SP around $60^{\circ} \mathrm{S}$, is characterized by the proximity between small and large icebergs, indicating that in these areas the small icebergs either calved from the large ones or in the same regions of Antarctica, then drift along similar paths.

[34] The second regime shows no direct relationship between the small and large icebergs. No small icebergs are closer than $200 \mathrm{~km}$ from a large one and the mean distance is larger than $800 \mathrm{~km}$. This regime corresponds to transport of ice due solely to small icebergs drifting over very long distances from their calving sources. For the 2002-2010 period, this is the exclusive regime for the eastern branch of the Wedell Gyre where no large icebergs are detected.
[35] The time-longitude diagram of the monthly proportion of icebergs whose distance to a large iceberg is smaller than $200 \mathrm{~km}$ (see Figure 14), also clearly shows the two regimes, and allows a clearer understanding of some of the ice distribution patterns observed in Figures 8-10. The large volume of ice observed in the SP north of $58^{\circ} \mathrm{S}$ in 2008 2009 results from the deterioration of the $\mathrm{C} 19 \mathrm{a}$ and $\mathrm{B} 15 \mathrm{a}$ tabular icebergs that drifted north and were caught in the ACC. Similarly, the trajectories of the A38-A and B tabular icebergs and in particular their grounding in January 2004 north east of South Georgia and their subsequent breaking into several pieces [Jansen et al., 2005] explain the high concentration of small icebergs observed in 2004 to the east of South Georgia. The diagram also shows that the small icebergs follows a diffusive process dispersing ice over much larger areas of the southern ocean than the large ones.

[36] However, the relation between small iceberg s volume of ice and the monthly number of large icebergs in open water (presented in Figure 15) is not straightforward. For example, while the number of large icebergs is above normal in 2008, especially during winter, the volume of small iceberg ice is one of the lowest of the 2002-2010 period. On the contrary, the lowest number of large icebergs is detected in 2006, characterized by a volume of ice almost double that of 2008. There might exist a more direct relationship but the (a)

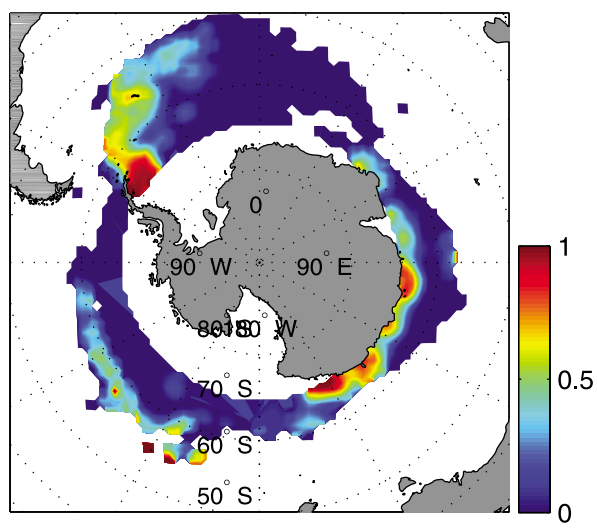

(b)

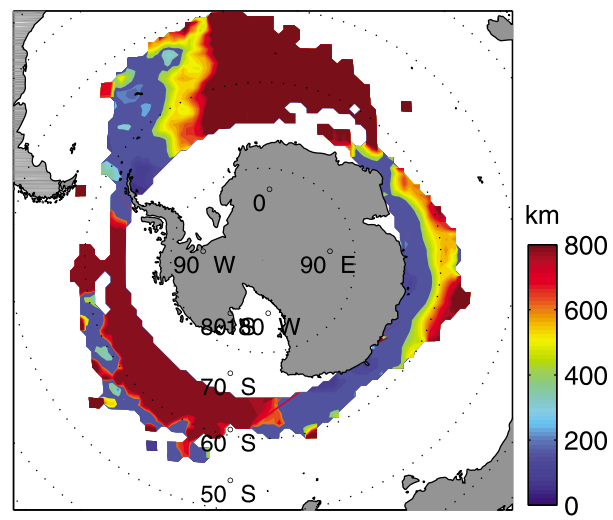

Figure 13. (a) Proportion of the small detected icebergs closer than $200 \mathrm{~km}$ to a large one and (b) mean distance of small icebergs to the closest large iceberg. 


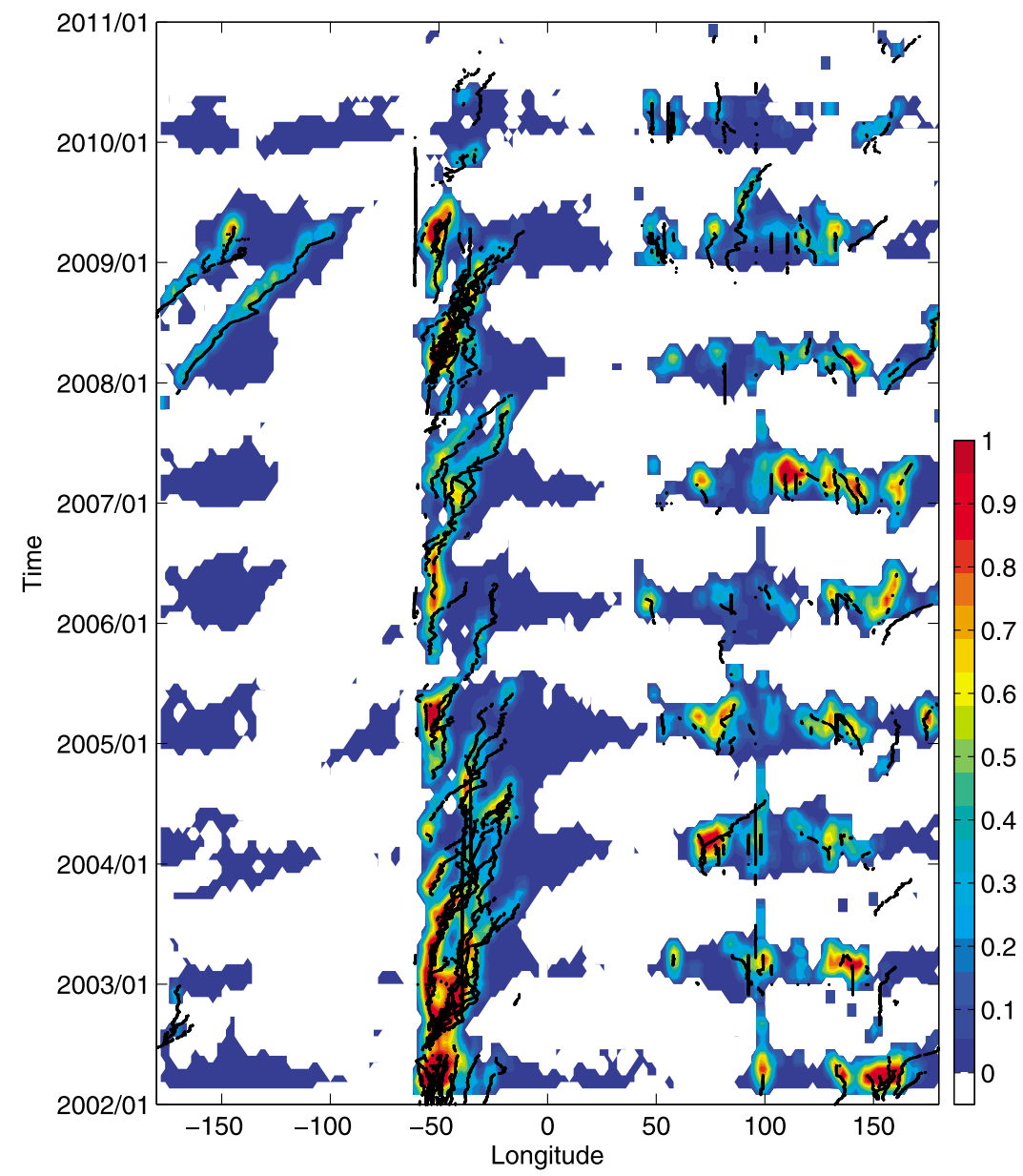

Figure 14. Longitude-time diagram integrated between $66^{\circ} \mathrm{S}$ and $50^{\circ} \mathrm{S}$ of the monthly mean proportion of small icebergs closer than $200 \mathrm{~km}$ to a large one. The black lines represents the trajectories of the BYU large icebergs in open water during the period.

pertinent parameters to analyze should be the volume of ice of the large icebergs, which is not yet routinely available.

[37] A method has been proposed by Stuart and Long [2011a] to estimate the size of large icebergs using SeaWinds data and in the future it will be possible to estimate the volume of large icebergs and analyze more precisely the relationship between small and large icebergs. Current progress with for example the Cryosat altimetry should also allow more systematic freeboard surveys of these icebergs.

\section{Fresh Water Flux}

[38] The transport of ice by small icebergs could represent, as mentioned earlier, about $40 \%$ of the volume of ice

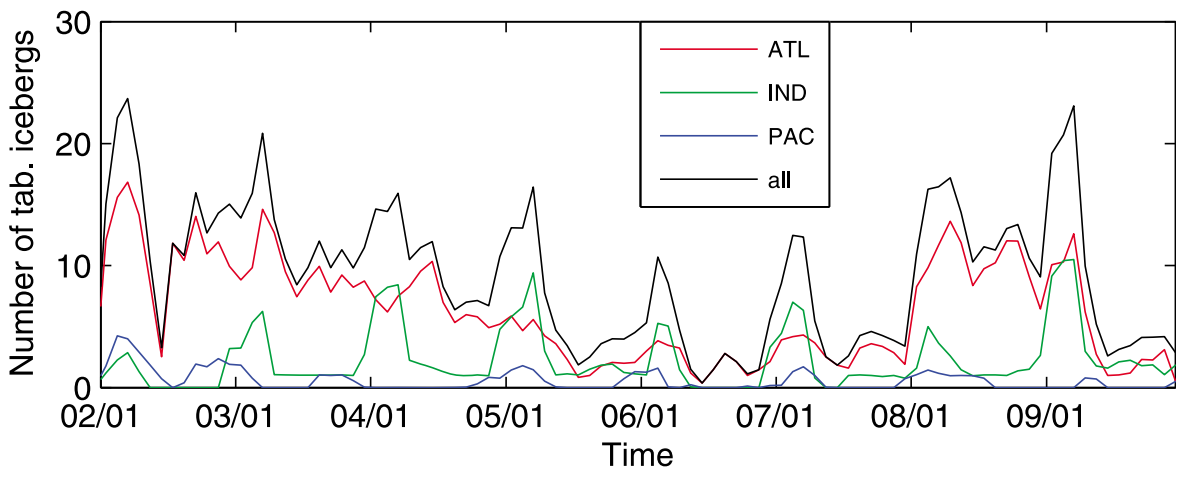

Figure 15. Monthly mean number of large icebergs from 2002 to 2010 in the South Atlantic Ocean (red line), the South Indian (green line), the South Pacific (blue) line and the southern ocean (black line). 


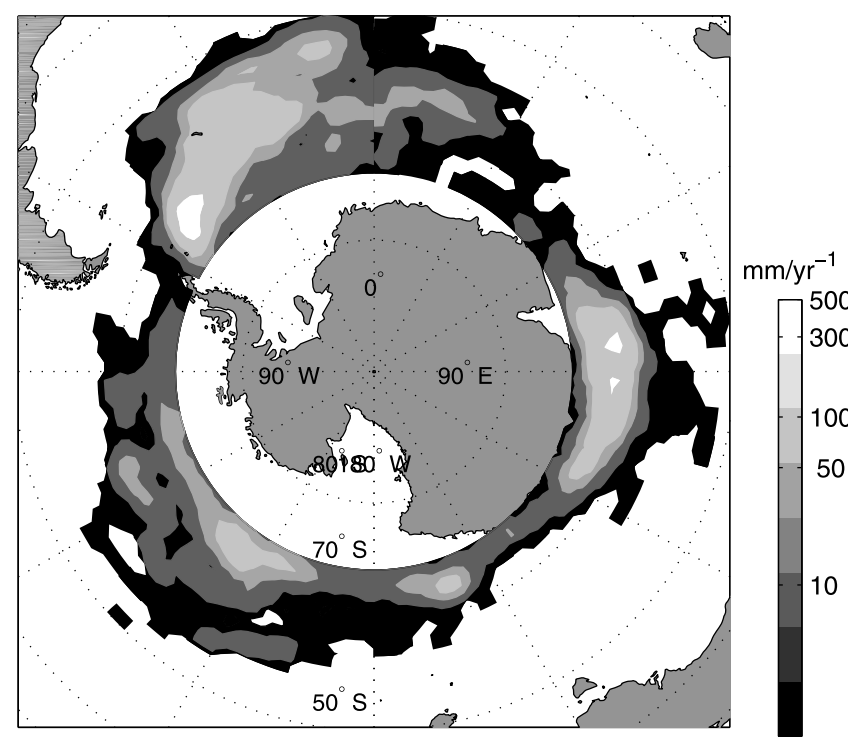

Figure 16. Mean annual available fresh water in $\mathrm{mm} \cdot \mathrm{yr}^{-1}$. The gray scale is logarithmic.

transported by icebergs and could thus have a significant role in the injection of fresh water in the ocean. The tracking of small icebergs is not possible using our iceberg data base and it is thus not yet possible to estimate the melting rate of individual icebergs or the associated fresh water flux. However, as the icebergs detected are small $(50 \%$ are smaller than $380 \mathrm{~m}$ length), their half-life should be of the order of 200 days according to Jacka and Giles [2007] and thus most of the ice detected in open water will most probably melt within a year. The difference between the maximum and minimum of the volume of ice observed during one year can thus be considered as a proxy to the available fresh water. This can give an insight to the regions of the southern ocean where fresh water is injected. It can also be used for comparison with model results such as the ones from Gladstone et al. [2001], Silva et al. [2006] and Martin and Adcroft [2010].

[39] Compared to the hundred year average of fresh water flux in the southern ocean presented by Martin and Adcroft [2010] using a coupled climate model including icebergs up to $2.2 \mathrm{~km}$ length, the distribution of the mean available fresh water presented in Figure 16 has the same range of values and overall patterns (see their Figure 2). However, in the SA, the flux in the Scotia Sea, the north-eastward transport by the ACC and the recirculation within the eastern branch of the Wedell Gyre are significantly larger in our estimate. In the SP and SI oceans, the overall patterns of the two distributions are quite similar but the northward transport of ice north of $66^{\circ} \mathrm{S}$ is one order of magnitude larger in our field.

[40] Similar results can be obtained by making a comparison with the model results of Gladstone et al. [2001], Silva et al. [2006] or Jongma et al. [2009], in particular, the underestimation of the Wedell Gyre recirculation or of the northward transport in the SP and SI oceans.

\section{Conclusion and Perspective}

[41] The method presented by Tournadre et al. [2008] to detect small icebergs in open water using high resolution altimeter waveforms has been improved to allow, assuming constant iceberg freeboard elevation and ice backscatter coefficient, the estimate of the iceberg area as well as the volume of ice and has been used to create a data base of more than 52,000 small icebergs covering the 2002-2010 period, i.e., the whole Jason-1 archive. The distribution of iceberg size and length follow a lognormal distribution in agreement with previous studies on the distribution of iceberg size based on ship-borne radars such as the one used by Wadhams [1988]. The best fit of this lognormal distribution gives a mean iceberg length of $630 \mathrm{~m}$ within the mean length given by Romanov et al. [2011] for different iceberg shapes and somewhat larger than the mean value of $513 \mathrm{~m}$ given by Wadhams [1988]. The iceberg size has a strong seasonal cycle reflecting the melting of icebergs during the austral summer that has been estimated at $1.5 \mathrm{~m} /$ day.

[42] The total volume of ice in the southern ocean has an estimated annual mean of about $400 \mathrm{Gt}$ with an uncertainty of $25-30 \%$. This represents about $35 \%$ of the volume of large tabular icebergs given by Silva et al. [2006] and it can thus play a significant role in the injection of meltwater in the ocean. The altimeter data allow to estimate the distribution of ice volume with unprecedented spatial and temporal resolutions revealing small scale structures and sporadic events such as the eastern Wedell Gyre recirculation or iceberg production in the Mertz Glacier area. They also show that the seasonal cycle of the volume of ice has a very high spatial and temporal inter-annual variability and this variability is much contrasted between the three ocean basins (South Atlantic, Indian and Pacific oceans). The small iceberg variability is at least partly due to the variability of large icebergs distribution and travel. Some events like the presence of the C19a and B15a icebergs in the South Pacific north of $60^{\circ} \mathrm{S}$ explains the anomalously high content of ice in this region in 2008 and 2009. However, the analysis of the relationship between small and large icebergs clearly reveals two different regimes, the first one characterized by the proximity of the two types of iceberg, corresponds to the main iceberg Alley or specific events where small icebergs (calved or not from large ones) and large ones travel in convoy along the same path. In such a regime, the small icebergs can be considered as diffusers of the ice contained in the large ones. The second one shows no or little relation between the two types and corresponds to a transport of ice over vast regions (for example the eastern branch of the Wedell Gyre or the eastern South Pacific ocean) and long distances solely by smaller icebergs. The lack of clear relation between the number of large icebergs present in open water and the volume of ice which shows that it is necessary to have an estimate of the size of the large ones (not yet available on an operational basis) to further investigate the small/large iceberg relationship.

[43] The small iceberg data set can not yet be used to track individual icebergs and it is thus not possible to estimate directly the melting rate or the associated fresh water flux. However, as the considered icebergs are small and have a half-life of the order of 200 days, the difference between the annual maximum and minimum of the volume of ice can be seen as a proxy to the available fresh water. The comparison with results from numerical models including iceberg drift and melting shows a good overall agreement of the patterns of the distribution and the range 
of value. However, in the SA, the flux in the Scotia Sea, the north-eastward transport by the ACC and the recirculation within the eastern branch of the Wedell Gyre are larger in our estimate.

[44] Small icebergs can therefore play a significant role in the transport of ice in the southern ocean, diffusing the ice of the large icebergs or of the Antarctic continent over large regions and over vast distances and should be taken into account for climatological, physical or biological oceanography studies.

[45] In the near future, we plan to increase the size of the small iceberg data base by adapting the method to other altimeters (ERS-1 and 2, Topex-Poseidon, Envisat and Jason-2) and make it available to the community. This will enable the analysis of the evolution of small icebergs over almost 20 years, once the homogeneity and consistency of the detection by the different altimeter is tested and validated. The data set can also be used to study the possible impact of small icebergs on the physical and biological properties of the southern ocean.

\section{Appendix A: Detection Method}

[46] The detection method used in the present study is a development of the one presented by Tournadre et al. [2008]. It is summarized here. An altimeter is a nadir looking radar that emits short pulses that are backscattered by the sea surface. The altimeter measures the backscattered power as a function of time to construct the echo waveform from which the geophysical parameters are estimated. The backscatter coefficient of the waveform can be expressed as a double convolution product of the radar point target response, the flat sea surface response and the joint probability density function of slope and elevation of the sea surface [Brown, 1977]. The radar cross section for backscatter as a function of time, $\sigma(t)$, assuming a Gaussian altimeter pulse, a Gaussian antenna pattern and a Gaussian random distribution of rough-surface specular points, can be expressed as [Barrick and Lipa, 1985]

$$
\sigma(t)=\frac{1}{2}(2 \pi)^{3 / 2} H^{\prime \prime} \sigma_{\tau} \sigma_{0}\left(1+\operatorname{erf}\left(\frac{x}{\sqrt{2} \sigma_{p}}\right)\right) e^{-\frac{x}{u_{b}}}
$$

where $x=c t / 2, H^{\prime \prime}=H /(1+H / a)$ is the reduced satellite height, $a$ being the earth's radius, and $H$ the satellite height. $\sigma_{\tau}$ is the standard deviation of the altimeter pulse; $\sigma_{p}=$ $\sqrt{h^{2}+\sigma_{\tau}^{2}}$ where $h$ is the RMS wave height; $u_{b}$ is the antenna pattern standard deviation; $\sigma_{0}$ is the target backscatter coefficient. It should be noted that $t=0$ corresponds to the mean sea level. The measured Jason-1 waveforms are given in telemetry samples of $3.125 \mathrm{~ns}$ width (the length of the pulse) and the nominal track point (i.e., the sea level or $\mathrm{t}=0$ ) is shifted to bin 32.5.

[47] A point target of height $\delta$ above sea level located at distance $d$ from the satellite nadir will give an echo at the time $t_{0}$ defined by [Powell et al., 1993]

$$
\frac{c t_{0}}{2}=-\delta+\frac{1}{2} \frac{a+H}{a H} d^{2}=-\delta+\frac{d^{2}}{2 H^{\prime \prime}} .
$$

The echo waveform of a point target is purely deterministic, i.e., a parabola as a function of time. Using the radar equation [Roca et al., 2003] it is of the form

$$
\sigma_{\text {target }}(t)=\frac{\sigma_{1}}{2 \pi^{2} H^{4}\left(1+\frac{d^{2}}{2 H^{2}}\right)} e^{-\frac{u_{0}}{u_{b}}} e^{-\frac{\left(x+\delta-u_{0}\right)^{2}}{2 \sigma_{\tau}^{2}}},
$$

where $\sigma_{1}$ is the target radar cross section, and $u_{0}=\frac{d^{2}}{2 H^{m}}$.

[48] For an iceberg of area $A$ and constant surface backscatter coefficient $\sigma_{1}$, the waveform is obtained by summation of (9) over $A$

$$
\sigma_{i c e}(t)=\frac{\sigma_{1}}{2 \pi^{2} H^{4}} \oint_{A} \frac{1}{1+\frac{d^{2}}{2 H^{2}}} e^{-\frac{u_{0}}{u_{b}}} e^{-\frac{\left(x+\delta-u_{0}\right)^{2}}{2 \sigma_{\tau}^{2}}} d A .
$$

To be detectable in echo waveforms, an iceberg should have an echo at a time, $t_{0}$ that lies within the time range during which the echo waveform is integrated, i.e., for Jason-1 between the telemetry sample 1 and 30 . The target backscatter coefficient should also be large enough to come out of the thermal noise of the sensor. This noise, estimated over more than 10 million waveforms has a mean value $-8.5 \mathrm{~dB}$ with a standard deviation of $1.3 \mathrm{~dB}$. The backscatter of an iceberg has to be larger than $-4.6 \mathrm{~dB}$ to come out of the thermal noise at a 3 std level. For icebergs larger than the altimeter footprint $\left(\sim 8-10 \mathrm{~km}^{2}\right.$, i.e., length $\left.>3 \mathrm{~km}\right)$, the change in surface elevation and the significant modification of the waveform shape is too rapid and causes the altimeter tracker to lose lock resulting in the loss of data for several seconds [Hawkins et al., 1991].

\section{A1. Iceberg Detection}

[49] The signature of icebergs is always characterized by the parabolic shape defined by (8). The automated detection is based on the analysis of the convolution product $C$ between a filter, $F$ characteristic of an iceberg signature, and the thermal noise sections of the waveforms

$$
C(i, j)=\sum_{n=1}^{30} \sum_{m=1}^{M_{2}} \sigma_{0}(i, j) F(i-n, j-m),
$$

where $i$ is the telemetry sample index, $j$, the waveform index, and $\sigma_{0}(i, j)$, the $j$ th waveform. The filter used has been computed by the waveform model of (10) for a $100 \times 100 \mathrm{~m}^{2}$ iceberg.

[50] For each waveform, the maximum of correlation $C(j)$ and its location $i_{\max }^{C}(j)$ (i.e., the range), and the maximum of backscatter, $\sigma_{\max }(j)$ and its location $i_{\max }^{\sigma}(j)$ are determined. A waveform is assumed to contain an iceberg signature if $C_{\max }(j)$ and $\sigma_{\max }(j)$ are larger than given thresholds $C_{1}$ and $\sigma_{1}$.

[51] For each signature a maximum of 40 waveforms can be involved [Tournadre et al., 2008]. If $n$ consecutive waveforms are detected as containing a signature, the time of the echo $\left(t_{\text {ech }}\right)$ is estimated as

$$
t_{e c h}=\left(32.5-\min \left(i_{\max }^{\sigma}(j), j=1 . . n\right)\right) * 3.125
$$

and the iceberg backscatter, $\sigma_{i c e b}$, is estimated as the maximum observed backscatter of the whole signature, i.e.,

$$
\sigma_{\text {iceb }}=\max \left(\sigma_{\max }(j), j=1 . . n\right) .
$$


[52] Acknowledgments. The large iceberg data base used in this study is produced by the Brigham Young University, Center for Remote Sensing, and is available at http://www.scp.byu.edu/data/iceberg/. The AMSR-E data sea ice concentration data are produced by the University of Bremen under the GMES project Polar View and are available at http://iup.physik.uni-bremen.de:8084/amsredata/asi aygrid $_{\mathrm{s}}$ wath/11a/s6250/. The CLS AVISO operation center generously supplied us with the Jason-1 sensor geophysical data record (SGDR). The authors also want to acknowledge financial support by the Centre National d'Etudes Spatiales (TOSCA program).

\section{References}

Barrick, D., and B. Lipa (1985), Analysis and interpretation of altimeter sea echo, in Satellite Oceanic Remote Sensing, Adv. Geophys. Ser., vol. 27, edited by B. Saltzman, pp. 61-100, Academic, Orlando, Fla.

Brown, G. S. (1977), The average impulse response of a rough surface and its applications, IEEE Trans. Antennas Propag., 25, 67-74.

Dowdeswell, J. A., and J. L. Bamber (2007), Keel depths of modern Antarctic icebergs and implications for sea-floor scouring in the geological record, Mar. Geol., 243, 120-131,doi:10.1016/j.margeo.2007.04.008.

Faugère, Y., J. Dorandeu, F. Lefevre, N. Picot, and P. Féménias (2006), Envisat ocean altimetry performance assessment and cross-calibration, Sensors, 6, 100-130.

Gladstone, R., and G. Bigg (2002), Satellite tracking of icebergs in the Weddell Sea, Antarct. Sci., 14, 278-287, doi:10.1017/S0954102002000032.

Gladstone, R. M., G. R. Bigg, and K. W. Nicholls (2001), Iceberg trajectory modeling and meltwater injection in the Southern Ocean, J. Geophys. Res., 106, 19,903-19,916, doi:10.1029/2000JC000347.

Glasby, G. P. (Ed.) (1990), Antarctic Sector of the Pacific, 396 pp., Elsevier, Amsterdam.

Hawkins, J., S. Laxon, and H. Phillips (1991), Antarctic tabular iceberg multi-sensor mapping, in International Geoscience and Remote Sensing Symposium, 1991. IGARSS '91. Remote Sensing: Global Monitoring for Earth Management, vol. 3, edited by Inst. of Electr. and Electron. Eng. Ed., pp. 1605-1608, New York.

Horn, P. S. (1990), Robust quantile estimators for skewed populations, Biometrika, 77, 631-636.

Jacka, T. H., and A. B. Giles (2007), Antarctic iceberg distribution and dissolution from ship-based observations, J. Glaciol., 53, 341-356.

Jansen, D., H. Sandh ager, and W. Rack (2005), Evolution of tabular iceberg A-38B, obsevation and simulation, FRISP Rep. 16, Alfred Wegener Inst., Helgoland, Germany.

Jongma, J. I., E. Driesschaert, T. Fichefet, H. Goosse, and H. Renssen (2009), The effect of dynamic-thermodynamic icebergs on the Southern Ocean climate in a three-dimensional model, Ocean Modell., 26(1-2), 104-113, doi:10.1016/j.ocemod.2008.09.007.

Keys, J., and D. Fowler (1989), Sources and movement of icebergs in the south-west Ross Sea, Antarctica, Ann. Glaciolog., 12, 85-88.

Klatt, O., E. Fahrbach, M. Hoppema, and G. Rohardt (2005), The transport of the Weddell Gyre across the prime meridian, Deep Sea Res., Part II, 52(3-4), 513-528, doi:10.1016/j.dsr2.2004.12.015.

Lancelot, C., A. de Montety, H. Goosse, S. Becquevort, V. Schoemann, B. Pasquer, and M. Vancoppenolle (2009), Spatial distribution of the iron supply to phytoplankton in the Southern Ocean: A model study, Biogeosciences, 6, 2861-2878.

Legrésy, B., F. Papa, F. Rémy, G. Vinay, M. Van den Bosch, and O.-Z. Zanife (2005), Envisat radar altimeter measurements over continental surfaces and ice caps using the ICE-2 retracking algorithm, Remote Sens. Environ., 95, 150-163.

Long, D., J. Ballantyne, and C. Bertoia (2002), Is the number of Antarctic icebergs really increasing?, Eos Trans. AGU, 83(42), 469, 474.

Martin, T., and A. Adcroft (2010), Parameterizing the fresh-water flux from land ice to ocean with interactive icebergs in a coupled climate model, Ocean Modell., 34(3-4), 111-124, doi:10.1016/j.ocemod.2010.05.001.

Ménard, Y., and L. Fu (2001), Jason-1 mission, Aviso Newsl., 8, 4-9.
Powell, R. J., A. R. Birks, W. J. Bradford, C. L. Wrench, and J. Biddiscombe (1993), Using transponders with ERS1-1 and Topex altimeters to measure orbit altitude to $\pm 3 \mathrm{~cm}, A d v$. Space Res., 13, 61-67.

Raiswell, R., L. G. Benning, M. Tranter, and S. Tulaczyk (2008), Bioavailable iron in the Southern Ocean: The significance of the iceberg conveyor belt, Geochem. Trans., 9, 1-23, doi:10.1186/1467-4866-9-7.

Roca, M., H. Jackson, and C. Celani (2003), RA-2 sigma-0 absolute calibration, paper presented at EGS-AGU-EUG Joint Assembly, Nice, France, 6-11 Apr.

Romanov, Y. A., N. A. Romanova, and P. Romanov (2008), Distribution of icebergs in the Atlantic and Indian Ocean sectors of the Antarctic region and its possible links with ENSO, Geophys. Res. Lett., 35, L02506, doi:10.1029/2007GL031685.

Romanov, Y. A., N. A. Romanova, and P. Romanov (2011), Shape and size of Antarctic icebergs derived from ship observation data, Antarct. Sci., 24, 77-87, doi:10.1017/S0954102011000538.

Schodlok, M. P., H. H. Hellmer, G. Rohardt, and E. Fahrbach (2006), Weddell Sea iceberg drift: Five years of observations, J. Geophys. Res., 111, C06018, doi:10.1029/2004JC002661.

Schwarz, J. N., and M. P. Schodlok (2009), Impact of drifting icebergs on surface phytoplankton biomass in the Southern Ocean: Ocean colour remote sensing and in situ iceberg tracking, Deep Sea Res., Part I, 56(10), 1727-1741, doi:10.1016/j.dsr.2009.05.003.

Silva, T., and G. Bigg (2005), Computer-based identification and tracking of Antarctic icebergs in sar images, Remote Sens. Envir., 94, 287-297, doi:10.1016/j.rse.2004.10.002.

Silva, T., G. Bigg, and K. Nicholls (2006), The contribution of giant icebergs to the Southern Ocean freshwater flux, J. Geophys. Res., 111, C03004, doi:10.1029/2004JC002843.

Smith, K. L. (2011), Free-drifting icebergs in the Southern Ocean: An overview, Deep Sea Res., Part II, 58(11-12), 1277-1284, doi:10.1016/j. dsr2.2010.11.003.

Soviet Antarctic Survey (1966), Antarctic Atlas, Moscow.

Spreen, G., L. Kaleschke, and G. Heygster (2008), Sea ice remote sensing using AMSR-E 89-GHz channels, J. Geophys. Res., 113, C02S03, doi:10.1029/2005JC003384.

Stuart, K., and D. Long (2011a), Iceberg size and orientation estimation using seawinds, Cold Reg. Sci. Technol., 69, 39-51, doi:10.1016/j. coldregions.2011.07.006.

Stuart, K. M., and D. G. Long (2011b), Tracking large tabular icebergs using the SeaWinds Ku-band microwave scatterometer, Deep Sea Res. Part II, 58(11-12), 1285-1300, doi:10.1016/j.dsr2.2010.11.004.

Tchernia, P., and P. F. Jeannin (1984), Circulation in antarctic waters as revealed by icebergs tracks 1972-1983, Polar Rec., 22, 263-269.

Tournadre, J. (2007), Signature of lighthouses, ships, and small islands in altimeter waveforms, J. Atmos. Oceanic Technol., 24, 1143-1149.

Tournadre, J., K. Whitmer, and F. Girard-Ardhuin (2008), Iceberg detection in open water by altimeter waveform analysis, J. Geophys. Res., 113 C08040, doi:10.1029/2007JC004587.

Tran, N., F. Rémy, H. Feng, and P. Féménias (2008), Snow facies over ice sheets derived from Envisat active and passive observations, IEEE Trans. Geosci. Remote Sens., 46(11), 3694-3708.

Tran, N., F. Girard-Ardhuin, R. Ezraty, H. Feng, and P. Féménias (2009), Defining a sea ice flag for Envisat altimetry mission, IEEE Geosci. Remote Sens. Lett., 6, 77-81, doi:10.1109/LGRS.2008.2005275.

Wadhams, P. (1988), Winter observations of iceberg frequencies and sizes in the South Atlantic Ocean, J. Geophys. Res., 93, 3583-3590.

Wilks, D. (2006), Statistical Methods in the Atmospheric Sciences, 2nd ed., Int. Geophys. Ser., vol. 59, 627 pp., Academic, Amsterdam.

Young, N. W. (1998), Antarctic iceberg drift and ocean current derived from scatterometer image series, paper presented at Workshop on Emerging Scatterometer Applications-From Research to Operations, Eur. Space Agency, Noordwijk, Netherlands, 5-7 Oct.

Young, N. W., D. Turner, G. Hyland, and R. N. Williams (1998), Near coastal iceberg distributions in east Antarctica, $50^{\circ} \mathrm{E}-145^{\circ} \mathrm{E}$, Ann. Glaciol., 27, 68-74. 